
\title{
25 Research Square \\ Oxidation Characteristics of Functional Groups in Relation to Coal Spontaneous Combustion
}

\author{
Yutao Zhang \\ Xi'an university of science and technology \\ Jing Zhang \\ Xi'an University of Science and Technology \\ Yaqing Li ( $\nabla$ lyqcumt@126.com ) \\ The University of Manchester Faculty of Biology Medicine and Health \\ Sheng Gao \\ Xi'an Qinhua Natural Gas \\ Chaoping Yang \\ Xi'an University of Science and Technology \\ Xueqiang Shi \\ Xi'an University of Science and Technology
}

Research

Keywords: coal spontaneous combustion, functional groups, in-situ FTIR spectra, aliphatic Hydrocarbons

Posted Date: April 30th, 2020

DOl: https://doi.org/10.21203/rs.3.rs-24891/v1

License: (c) (1) This work is licensed under a Creative Commons Attribution 4.0 International License. Read Full License

Version of Record: A version of this preprint was published at ACS Omega on March 12th, 2021. See the published version at https://doi.org/10.1021/acsomega.0c06322. 


\section{Abstract}

To investigate the mechanism of coal spontaneous combustion, distributions, evolutions, and oxidation characteristics of functional groups in different coals were characterized by employing in-situ FTIR, EPR, and TG/DSC-FTIR experiments. Experimental results indicated that $-\mathrm{OH}$ was the most active groups of coal spontaneous combustion. It not only could react with the absorbed oxygen spontaneously but also thebe the main product of the chemisorption. Consequently, $-\mathrm{OH}$ was believed to contribute most both for the loss and increase of coal massduring the process of spontaneous combustion. Aliphatic hydrocarbons were the main components to form $-\mathrm{C}-\mathrm{O}-\mathrm{O} \cdot$ and could be further oxidized into $\mathrm{C}=\mathrm{O}$. However, reactions between aliphatic hydrocarbons and oxygen were non-spontaneous.EPR experiments suggested that the tendency of coal spontaneous combustion acutely depended on the stability and survival time of free radicals. The more stable and longer survival time of free radicals are, the lower tendency of coal spontaneous combustion is.

\section{Introduction}

Coal is the most abundant energy resource with significant remaining reserves in China. However, the spontaneous combustion continues to be a big challenge associated with the production, storage, and transportation of coal. It has been reported that more than $70 \%$ of the total mine fires in China are resulted from spontaneous combustion. The spontaneous combustion may lead to coal ignition, a fullblown fire, and even explosion if it is not eradicated appropriately. This may not only result in interruption of operations and mine closures, but serious losses of miners' lives(Zhang et al. 2018a; Xu et al. 2017). As the necessity for ensuring safe production, storage, and transportation of coal, the prevention and control of coal spontaneous combustion has become increasingly vital.

Mechanism of coal spontaneous combustion is the foundation to prevent and control the coal fires efficiently and effectively. As early as the 17th century, coal spontaneous combustion had attracted a widespread concern in the industry. Soon after, a variety of theories, such as Pyrite Inducting theory, Bacteria Inducing theory, Phenolic Hydroxyl Inducing theory, Coal-oxygen Complex theory, etc., have been posed to explain the phenomena of coal spontaneous combustion. Among them, the Coal-oxygen Complex theory is in accordance with the macroscopic characteristics of coal spontaneous combustion and therefore has been widely accepted(Wang 2008). However, this theory cannot clearly explain the microscopic process such as species of functional groups reacting with oxygen, reacting conditions, and reacting characteristics so far.

Following the interpretation of Coal-oxygen Complex theory, heat accumulation is the direct cause of coal spontaneous combustion. Therefore, lots of studies toward basic understanding of mechanism of coal spontaneous combustion using thermal analysis technology have been presented. Pilar et al. (1999)calculated kinetic parameters of different coal samples and analyzed the process of coal spontaneous combustion from the standpoint of activation energy. Pis et al. (1996)compared oxidation characteristics of raw coal and oxidized coals. They found that characteristic temperatures of oxidized 
coals increased regardless of coal properties. Wang(2013)evaluated the effects of heating rate on the characteristic of coal spontaneous combustion and found that exothermic profiles of coal samples shifted to higher temperatures with the increase of heating rates. Yu et al.(2007) found that the heat released at the coal oxidation stage was much higher than that at the pyrolysis stage. Xiao et al. (2007)and Zhang et al.(2018b,2017)defined characteristic temperatures during coal spontaneous combustion according to thermogravimetric curves. Based on experimental results, Deng et al.(2018) concluded that temperatures of thermal decomposition and the maximum rate of weight loss were critical to reflect the severity of coal spontaneous combustion. Zhang et al.(2018c)proposed a DSC inflection method to determine auto-ignition temperatures of coals during the spontaneous combustion process. Actually, heat release is only the outward manifestation and an accompanying effect of reactions during the coal spontaneous combustion. The essential cause was the productions and evolutions of diverse functional groups. Consequently, identifying and characterizing the oxidation characterizations of functional groups during the spontaneous combustion have been of interest.

Fourier Transform Infrared Spectrometer (FTIR) technique is a commonly used method to study the functional groups in coals(Dyrkacz et al. 2001). Based on FTIR spectra, substantial achievements have been obtained. Petersen(2006a, 2006b) speculated structural parameters of coals using FTIR. Ibarra et al. (1996)identified the distributions of aromatic hydrocarbons and oxygen-containing species in coals. Zhang et al. (2013)addressed that the occurrence of coal spontaneous combustion was the result of reactions between active groups and oxygen molecules. Further, active groups in coals were classified into oxygen-containing and oxygen-free groups by Yang et al.(2005). Encouraged by this finding, the free radical action hypothesis was proposed by Li(1996)and tried to explain the mechanism of coal spontaneous combustion from the standpoint of chemistry. By analysis of oxygen distribution during the process of coal spontaneous combustion, Retcofsky et al.(1968)validated the reasonability of the free radical action hypothesis. Afterward, quite a few studies have been conducted to investigate mechanism of coal spontaneous combustion by employing EPR technique. Wood et al.(1992)observed that concentrations of free radicals in oxidized coal samples were higher than that of raw coals. Dai (2011)pointed out that the intensity of coal oxidation during the process of spontaneous combustion was determined by the amount of generated free radicals rather than that of original. In addition, influencing factors on characteristics of free radicals in coals have been experimentally studied(Cerny et al. 1994; Li et al.2002; Liu et al. 2014; Liu et al. 2015). However, both the FTIR technique and EPR technique could not quantify functional groups that changed with the oxidation processes. Consequently, the theories regarding to the mechanism of coal spontaneous combustion were still limited to hypothesis. To address this issue, the quantum chemical technology was employed to derivate the chemical reactions of functional groups during the process of coal spontaneous combustion. Based on quantum computation, models of molecular that could be easily oxidized were constructed(Wang et al.2014). The reacting sequences and steps of these active groups were calculated as well(Shiet al. 2004;Wanget al 2014; Shi at al.2005). Although the quantum chemistry has led to many advances in calculating chemical reactions of coal spontaneous combustion, few experiments were conducted to verify the accuracy of quantum chemical calculations so far. 
In this study, the in-situ FTIR technology combined with EPR technique were employed to characterize evolutions of multifarious functional groups as well as their oxidation characteristics. Meanwhile, oxidation characterizations of the functional groups in relation to macroscopic characteristics of coal spontaneous combustion were investigated on the basis of TG/DSC-FTIR experiments. This study would not only be beneficial for revealing the mechanism of coal spontaneous combustion but also may provide theoretical foundations for development of fire extinguishing materials.

\section{Experimental}

\subsection{Coal Samples}

Three coals with different properties from Xinjiang, Huainan, and Anhui provinces in China were selected in this study. The proximate analysis of each coal was listed in Table 1. According to ISO 11760 Classification of Coal, C1, C2, and C3 could be categorized into lignite, bituminous coal, and anthracite, respectively (Cerny et al.1994).

A two-step crushing process was employed to prepare coal samples. Firstly, raw coals with different properties were crushed to minus 5 millimeters with a Jaw crusher. Then, the crushed coals were further ground to minus 74 microns in a hammer mill. To avoid oxidation, both the crushing and grinding processes were finished under the atmosphere of $\mathrm{N}_{2}$. After subjecting to riffling, coning, and quartering processes, ground coal samples were put into well-sealed flasks for tests.

Table 1 Codes and roperties of coal samples.

\begin{tabular}{ccccc}
\hline Code of Samples & \multicolumn{4}{c}{ Proximate analysis, wt. \% } \\
\cline { 2 - 5 } & $\mathrm{M}_{\mathrm{ad}}$ & $\mathrm{A}_{\mathrm{ad}}$ & $\mathrm{V}_{\mathrm{ad}}$ & $\mathrm{FC}_{\mathrm{ad}}$ \\
\hline $\mathrm{C} 1$ & 25.37 & 7.46 & 52.25 & 14.92 \\
$\mathrm{C} 2$ & 1.81 & 14.62 & 33.36 & 50.21 \\
$\mathrm{C} 3$ & 1.89 & 13.03 & 9.50 & 75.58 \\
\hline
\end{tabular}

\subsection{Experiments Setup}

\subsubsection{In-situ FTIR Experiments}

To characterize functional groups in different coal samples as well as their evolutions during the spontaneous combustion, an in-situ FTIR experimental system was set up to carry out the experiments. Figure 1illustrated the schematic of the system. The system consists of a VERTEX70v series FTIR manufactured by Bruker Incorporation and a diffuse reflection in-situ cell. During each experimental run, a $15 \mathrm{mg}$ coal sample was oxidized from 25 to $430^{\circ} \mathrm{C}$ in the cell at an increasing rate of $1^{\circ} \mathrm{C} / \mathrm{min}$. The 
wavenumber of FTIR was set to be between 400 and $4000 \mathrm{~cm}^{-1}$ with a resolution of $4 \mathrm{~cm}^{-1}$ and the data collecting frequency was $32 \mathrm{~Hz}$. The functional groups were categorized on the basis of Table 2 .

\subsubsection{EPR Experiments}

Free radicals allow one to essentially understand the oxidation process of coal. The Electron Paramagnetic Resonance (EPR) technique, which can directly detect unpaired electrons of molecules, plays an important role in determination of free radicals in coals. To deeply investigate the oxidation characteristics of functional groups during the coal oxidation process, an EMSplus-10-12 EPR systems manufactured by Bruker Incorporation was employed to characterize free radicals of different coal samples. The schematic and set-up of the apparatus is shown in Fig. 2 Basically, the apparatus was composed of a microwave bridge, a resonant cavity, a magnet, a control box, a main engine, and a water cooling system.

For each experimental run, a $15 \mathrm{mg}$ prepared coal sample was put into the sample bin with a diameter of 4 millimeters for test. For the purpose of experiments, 3360G magnetic flux was loaded and the radiation frequency of microwave was set to be $935 \mathrm{MHz}$. The scanning time was $40 \mathrm{~s}$ with a magnification of 20 .

\subsubsection{TG/DSC-FTIR Experiments}

A STA 449 F3 series simultaneous TG/DSC thermal analyzer of Netzsch Incorporation coupled with a VERTEX 70v serious FTIR manufactured by Bruker Incorporation system was set up to conduct relative tests, as illustrated in Fig. 3. In this experimental system, the coal sample was oxidized in the TG/DSC thermal analyzer and the gaseous products were delivered to FTIR via a specially designed interface in real time for identification.

For each experimental run, a $15 \mathrm{mg}$ coal sample was put into the sample bin of the TG/DSC analyzer and heated from 25 to $430^{\circ} \mathrm{C}$ with an increment of $5^{\circ} \mathrm{C} / \mathrm{min}$. Nitrogen was selected as the protection gas and the total flow rate of the protection and carrier gases was kept constant at $100 \mathrm{ml} / \mathrm{min}$. For the purpose of the study, the oxygen concentration in the carrier gas was adjusted to $21 \%$. The wavenumber of the FTIR was set to be between 400 and $4000 \mathrm{~cm}^{-1}$ with a resolution of $4 \mathrm{~cm}^{-1}$. To avoid condensation of the gaseous products, temperatures of the interface and the transmission line were both kept constant at $220^{\circ} \mathrm{C}$.

\section{Results And Discussion}

\subsection{Distribution of Functional Groups}

FTIR spectra of different coal samples were fitted by employing Peakfit software and assigned to specific functional groups on the basis of Table 2. Results are illustrated in Fig. 4. To emphasize comparisons, corresponding regression curves were also illustrated in Fig. 4. Based on peak areas of the regression curves, relative contents of functional groups were obtained and summarized in Table 3. 
Data listed in Table 3 indicated that functional groups in coals, in general, can be classified into three types including oxygen-bearing groups, aliphatic hydrocarbons, and aromatic hydrocarbons (Zhang et al 2019; Xu et al. 2012). Of them, the content of the oxygen-bearing groups were the largest, accounting for more than $50 \%$ and that of the aliphatic hydrocarbons was the least. Furthermore, it was found that oxygen-bearing groups in the tested coal sample were existed in the forms of $-\mathrm{OH}, \mathrm{C}=\mathrm{O}$, - $\mathrm{COO}$ - and -C-O$\mathrm{C}$-. This finding was consistent with the molecular models of coals constructed by Mathews and Chaffee (Mathews et al. 2012).Connected to this finding was that aliphatic hydrocarbons in coals were present either as the mode of $-\mathrm{CH}_{3}$ or $-\mathrm{CH}_{2}$ - Aromatic hydrocarbons, as the backbone of the coal molecule, were characterized by stretching vibrations of $\mathrm{Ar}-\mathrm{CH}$ and $\mathrm{C}=\mathrm{C}$ on aromatic or condensed nucleuses, located at 3026 and $1614 \mathrm{~cm}^{-1}$, respectively. Further analysis of data listed in Table 2suggested that the contents of aliphatic hydrocarbons and aromatic hydrocarbons were increased with the coalification. Nevertheless, an opposite change was observed for oxygen-bearing groups. It is a practical cognition that the lower the coalification is, the easier the coal tends to spontaneous combustion. Combing experimental results with the practical cognition lead to the statement that oxygen-bearing groups were of importance for the tendency of coal spontaneous combustion.

Table 2 Categories and motions of functional groups based on wavenumbers [33].

\begin{tabular}{|c|c|c|}
\hline $\begin{array}{l}\text { Wavenumber } \\
\left(\mathrm{cm}^{-1}\right) \\
\end{array}$ & Functional groups & Motion of functional groups \\
\hline 750 & $-\mathrm{OH}$ & Bending vibration of $-\mathrm{OH}$ in alcohol or phenolic molecules \\
\hline 786 & $\mathrm{C}-\mathrm{H}$ & Bending vibration of $\mathrm{C}-\mathrm{H}$ in $1,2,3$ substituted benzene \\
\hline 912 & $\mathrm{C}-\mathrm{H}$ & Out-of-plane bending vibration of $\mathrm{C}-\mathrm{H}$ in Aldehydic molecules \\
\hline $1002-1174$ & $\mathrm{C}-\mathrm{O}-\mathrm{C}$ & Stretching vibration of $-\mathrm{C}-\mathrm{O}-\mathrm{C}-$ \\
\hline 1355 & $-\mathrm{CH}_{3}$ & Shear vibration of $-\mathrm{CH}_{3}$ \\
\hline 1396 & $-\mathrm{CH}_{3},-\mathrm{CH}_{2}^{-}$ & In-plane bending vibration of $\mathrm{C}-\mathrm{H}$ \\
\hline 1440 & $-\mathrm{CH}_{2}^{-}$ & Shear vibration of $-\mathrm{CH}_{2}^{-}$ \\
\hline 1618 & $\mathrm{C}=\mathrm{C}$ & Stretching vibration of $\mathrm{C}=\mathrm{C}$ on aromatic or condensed nucleuses \\
\hline 1637 & $\mathrm{C}=\mathrm{O}$ & Stretching vibration of $\mathrm{C}=\mathrm{O}$ \\
\hline $2780-2350$ & $-\mathrm{COO}-$ & Stretching vibration of -COO- \\
\hline 2921 & $-\mathrm{CH}_{3}$ & Stretching vibration of $\mathrm{C}-\mathrm{H}$ in $-\mathrm{CH}_{3}$ \\
\hline 2989 & $-\mathrm{CH}_{2}^{-}$ & Stretching vibration of $\mathrm{C}-\mathrm{H}$ in $-\mathrm{CH}_{2}-$ \\
\hline $3100-3000$ & $\mathrm{Ar}-\mathrm{CH}$ & Stretching vibration of $\mathrm{C}-\mathrm{C}$ on aromatic rings \\
\hline 3415 & $-\mathrm{OH}$ & Associating hydrogen bond of - $\mathrm{OH}$ among molecules \\
\hline
\end{tabular}

Table 3 Percentages of main functional groups for different coal samples.

\begin{tabular}{cccccccccc}
\hline Samples & Aliphatic hydrocarbons, $\%$ & \multicolumn{2}{l}{ Aromatic hydrocarbons, $\%$} & \multicolumn{3}{c}{ Oxygen-bearing groups, \% } \\
\cline { 2 - 10 } & $\left(-\mathrm{CH}_{3} /-\mathrm{CH}_{2}-\right)$ & $\mathrm{C}=\mathrm{C}$ & $\mathrm{Ar}-\mathrm{CH}$ & Subtotal & $-\mathrm{OH}$ & $\mathrm{C}=\mathrm{O}$ & $-\mathrm{C}-\mathrm{O}-\mathrm{C}-$ & $-\mathrm{COO}-$ & Subtotal \\
\hline $\mathrm{C} 1$ & 11.05 & 16.25 & 1.53 & 17.78 & 43.56 & 7.84 & 14.65 & 5.12 & 71.17 \\
\hline $\mathrm{C} 2$ & 15.82 & 20.37 & 2.16 & 22.53 & 36.21 & 2.87 & 20.63 & 1.94 & 61.65 \\
\hline $\mathrm{C} 3$ & 16.95 & 26.66 & 6.33 & 32.99 & 13.94 & 4.65 & 28.75 & 2.72 & 50.06 \\
\hline
\end{tabular}


Fig. 5 illustrated the relative contents of oxygen-bearing groups in different coal samples. It wasnotable that $-\mathrm{OH}$ and $-\mathrm{C}-\mathrm{O}-\mathrm{C}$ - accounted for the majority of the oxygen-bearing groups regardless of coal properties. Nevertheless, contents of $\mathrm{C}=\mathrm{O}$ and-COO- were negligible. Furthermore, it was observed that the content of-C-O-C- increased as the coalification. On the contrary, the larger content of $-\mathrm{OH}$ was observed for the coal sample with lower degree of coalification. Due to the high polarity, $-\mathrm{OH}$ was believed to be the main functional group in coal molecules to form hydrogen bonds. Different hydrogen bonds could be formed when $-\mathrm{OH}$ combined with different acceptors. According to Fei et al. (2002), $-\mathrm{OH}$ in coals existed in three forms including free $-\mathrm{OH}$, intermolecular-associated $-\mathrm{OH}$, and self-associated $-\mathrm{OH}$ whose infrared vibration peaks were located at $3674 \mathrm{~cm}^{-1}, 3535 \mathrm{~cm}^{-1}$, and $3428 \mathrm{~cm}^{-1}$, respectively. Relative contents of these three forms of $-\mathrm{OH}$ for tested coal samples were obtained and displayed in Fig. 6.Graphs inFig. 6 depicted that the intermolecular-associated $-\mathrm{OH}$ was acutely dependent on the properties of coal samples. With the increase of coalification, contents of the intermolecular-associated -OH decreased from $27.28 \%$ to $2.47 \%$. The same trend was observed for self-associated $-\mathrm{OH}$. On the contrary, contents of the free $-\mathrm{OH}$ increased from $2.79 \%$ for lignite to $9.32 \%$ for anthracite. This observation implied that the contribution of the hydrogen bond for the reactivity of coal diminished with the increase of the coalification.

Figure 7 displayed the distributions of $-\mathrm{CH}_{3}$ and $-\mathrm{CH}_{2}$ - in various coal samples. The ratio of $-\mathrm{CH}_{2}$ - to $-\mathrm{CH}_{3}$ usually indicated the length of branched chains and a high ratio represented a longer branched chain ( $\mathrm{Yu}$ et al.2006). Graphs in Fig. 7indicated thatthe ratio of- $\mathrm{CH}_{2}$ - to $-\mathrm{CH}_{3}$ from high to low was in an order of $\mathrm{C} 2$, $\mathrm{C} 1$, and $\mathrm{C} 3$. This order indicated that the chain of the branched aliphatic hydrocarbons in $\mathrm{C} 2$ was the longest, followed by $\mathrm{C} 1$ and $\mathrm{C} 3$.

\subsection{Evolution of Oxygen-Bearing Groups with Temperatures 3.2.1 Evolution of -OH with Temperatures}

As mentioned above, $-\mathrm{OH}$ is of vital importance during the spontaneous combustion of coal. As a result, the investigation for the evolution of $-\mathrm{OH}$ was beneficial for the deep understanding of the microcosmic mechanism of coal oxidation. Figure 8showed the response of $-\mathrm{OH}$ to temperatures. Curves in Fig. 8(a) implied that the free $-\mathrm{OH}$ in $\mathrm{C} 1$ and $\mathrm{C} 2$ decreased sharply at $50-120^{\circ} \mathrm{C}$. On the basis of $\mathrm{TG}$ and DSC curves, the process of coal spontaneous combustion could be classified into Dehydration and Desorption Stage, Oxidation Stage, Combustion Stage, and Burn-out Stage (Wang et al. 2014). According to this classification standard, the decrease of the free $-\mathrm{OH}$ at the temperature range of 50 to $120^{\circ} \mathrm{C}$ indicated that the free -OH was mainly involved in the Dehydration and Desorption Stage. A small decrease of free $\mathrm{OH}$ at temperatures exceeding $250^{\circ} \mathrm{C}$ in $\mathrm{C} 3$ coal implied that the free $-\mathrm{OH}$ in coals was also involved in the reactions during the Oxidation Stage.

Figure 8(b) illustrated that the intermolecular-associated - $\mathrm{OH}$ of $\mathrm{C} 1$ decreased as the temperature rose from the beginning. Analysis of the curves in Fig. 8(b) indicated that the content of the intermolecularassociated $-\mathrm{OH}$ in $\mathrm{C} 2$ exhibited a small decrease when the temperature increased from 25 to $170^{\circ} \mathrm{C}$. 
However, further increasing the temperature to $342^{\circ} \mathrm{C}$ resulted in an increase of the intermolecularassociated $-\mathrm{OH}$ for $\mathrm{C} 2$. Afterwards, a significant decrease was observed for $\mathrm{C} 2$ after $342^{\circ} \mathrm{C}$. For $\mathrm{C} 3$, the intermolecular-associated $-\mathrm{OH}$ was kept almost constant before $260^{\circ} \mathrm{Cand}$ increased as the temperature went up from 260 to $430^{\circ} \mathrm{C}$. The decreases for $\mathrm{C} 1$ and $\mathrm{C} 2$ indicated that the intermolecular-associated $\mathrm{OH}$ had a high reactivity and participated in the reactions spontaneously. Nevertheless, the behaviors of $\mathrm{OH}$ responded to the temperature for $\mathrm{C} 2$ and $\mathrm{C} 3$ suggested that new intermolecular-associated $-\mathrm{OH}$ was generated with the consumptions of the original ones during the reactions. Based on the quantum chemistry, functional groups of $-\mathrm{CH}_{3},-\mathrm{CH}_{2}$, and $-\mathrm{CHCH}_{3}-\mathrm{CH}_{2}$ - in coals were speculated to react with oxygen as follows:
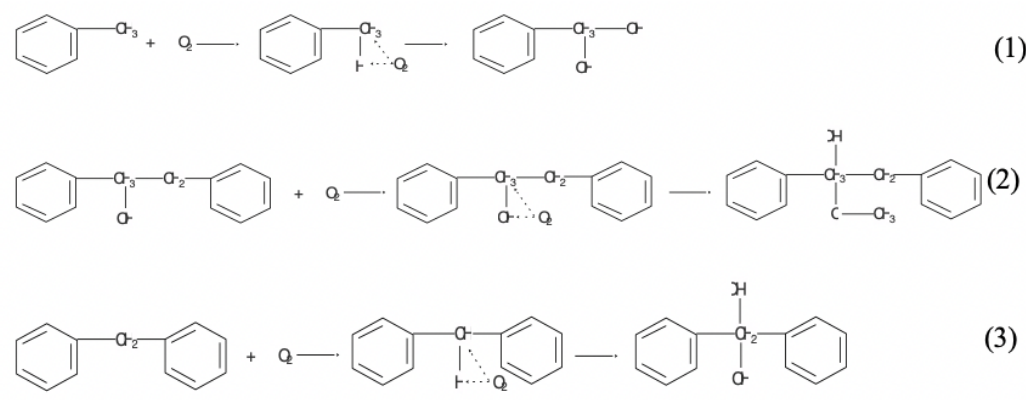

Apparently, the generation of intermolecular-associated -OH during the process of coal spontaneous combustion strongly supported the rationality of these three speculations. Substituting these three speculations into the behaviors of the intermolecular-associated - $\mathrm{OH}$ in $\mathrm{C} 2$ and $\mathrm{C} 3$ would lead to the conclusion that energy had to be provided to induce the reactions illustrated inEqs. 1-3. Moreover, it was observed that the temperature at which the intermolecular-associated - $\mathrm{OH}$ started to increase for $\mathrm{C} 2$ was higher than that for $\mathrm{C} 3$. Combining this observation with the previous finding that the chain of the branched aliphatic hydrocarbons in $\mathrm{C} 2$ was the longest, it could be concluded that the shorter side chain would cause a higher reactivity.

\subsubsection{Evolution of $\mathrm{C}=0$ with Temperatures}

The stretching vibration of the $C=0$ was located at the wavelengths between 1780 and $1630 \mathrm{~cm}^{-1}$. Based on experimental results, the strongest absorbance at $1776 \mathrm{~cm}^{-1}$ was selected as the representative to investigate the response of $\mathrm{C}=0$ to the temperature. Results were plotted inFig. 9.

Curves in Fig. 9 illustrated that contents of $\mathrm{C}=0$ increased with temperatures before the temperature exceeded thresholds of $341^{\circ} \mathrm{C}$ for $\mathrm{C} 1$ and $389^{\circ} \mathrm{C}$ for $\mathrm{C} 2$, respectively. After exceeding these thresholds, the contents of $\mathrm{C}=0$ gradually decreased. This illustration suggested that $\mathrm{C}=0$ was an important transition functional groups during coal spontaneous combustion process. Before the thresholds, the formation of $\mathrm{C}=\mathrm{O}$ was prominent, correlating with previous findings of other researchers(Dack et al.1983;Kudynska et al.1996;Liottar et al.1983). Based on the principles of chemical reactions, C = 0 could be produced as follows: 


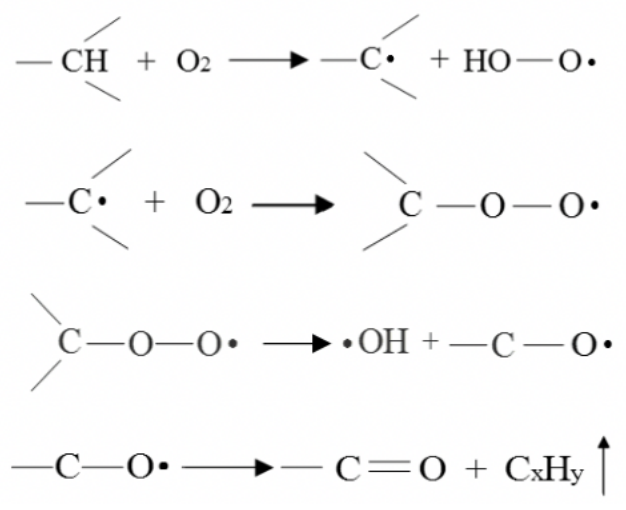

Firstly, aliphatic hydrocarbons were attacked by oxygen, resulting in the $\mathrm{C} \cdot$. Further, $\mathrm{C} \cdot$ was transformed into $-\mathrm{C}-\mathrm{O}-\mathrm{O} \cdot$ by oxygen. Successively, $\mathrm{-C}-\mathrm{O}-\mathrm{O} \cdot$ was converted into unstable $\cdot \mathrm{OH}$ and-C-O $\cdot-\mathrm{C}-\mathrm{O} \cdot$ was then decomposed into $\mathrm{C}=\mathrm{O}$ and gases of $\mathrm{C}_{\mathrm{x}} \mathrm{H}_{\mathrm{y}}$. Following this explanation, aliphatic hydrocarbons were speculated to be the main components to form -C-O-O. The conclusion was well supported by curves in Fig. 9. Meanwhile, it was observed that contents of $\mathrm{C}=\mathrm{O}$ in $\mathrm{C} 2$ and $\mathrm{C} 3$ almost kept constant until the temperatures exceeded thresholds. This observation further confirmed the previous finding that aliphatic hydrocarbons and oxygen could not react spontaneously unless enough energy was provided.

\subsubsection{Evolution of -COO- with Temperatures}

Fig. 10plotted the evolution of -COO-against temperatures. It is noteworthy that - $\mathrm{COO}$ - in $\mathrm{C} 1$ started to decrease at the beginning of coal spontaneous combustion. Nevertheless, contents of -COO- in C2 and C3 kept almost unchanged during the whole experimental process. This was because - $\mathrm{COO}$ - in $\mathrm{C} 1$ was mainly existed in the form of - $\mathrm{COOH}$; while - $\mathrm{COO}$ - in $\mathrm{C} 2$ and $\mathrm{C} 3$ were primarily present in ester groups. Therefore, the response of - $\mathrm{COO}$ - in $\mathrm{C} 1$ to temperatures indicated that $-\mathrm{COOH}$ in coals was featured with a high reactivity.

\subsection{Evolution of Aliphatic Hydrocarbons with Temperatures}

According to Table 2 the main motions of branched aliphatic hydrocarbons include the stretching vibration of $\mathrm{C}-\mathrm{H}$ bond in $-\mathrm{CH}_{3}$ and $-\mathrm{CH}_{2}$ - located between $2921 \mathrm{~cm}^{-1}$ and $2989 \mathrm{~cm}^{-1}$. The strongest absorbance of $\mathrm{C}-\mathrm{H}$ bond at $2918 \mathrm{~cm}^{-1}$ was selected as the representative to investigate the behavior of branched aliphatic hydrocarbons during the process of coal spontaneous combustion. Results were displayed in Fig. 11.

Curves in Fig. 11 illustrated that contents of aliphatic hydrocarbons almost kept constant before the temperatures reached to certain values in spite of coal properties. However, they suddenly decreased when the temperature exceeded thresholds. The changes indicated that energy was required for $-\mathrm{CH}_{3}$ and $-\mathrm{CH}_{2}$ - to fracture or to participate into chemical reactions. This suggestion emphasized the previous conclusion that reactions between oxygen and $-\mathrm{CH}_{3}$ or $-\mathrm{CH}_{2}$ - in coals were non-spontaneous.

Based on curves in Fig. 11, the temperatures when $-\mathrm{CH}_{2}$ - and $-\mathrm{CH}_{3}$ started to decrease were $202^{\circ} \mathrm{C}$ for $\mathrm{C} 1$, $215^{\circ} \mathrm{C}$ for $\mathrm{C} 2$, and $178^{\circ} \mathrm{C}$ for $\mathrm{C} 3$. These data was consistent with the previous statement that the shorter 
the side chains were, the stronger tendency of coal towards spontaneous combustion would be. This was mainly attributed to the high susceptibility of side chains to heat and chemical reactions.

\subsection{Evolution of Aromatic Hydrocarbons with Temperatures}

Aromatic hydrocarbons in the coal samples could be classified into $\mathrm{C}=\mathrm{C}$ and $\mathrm{Ar}-\mathrm{CH}$. According to Table 2

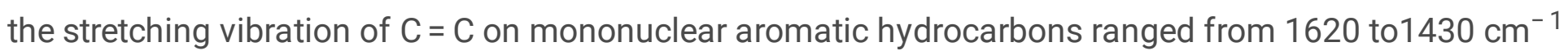
and that of $\mathrm{Ar}-\mathrm{CH}$ on aromatic hydrocarbons was in the range between 3100 and $3000 \mathrm{~cm}^{-1}$. Consequently, the strongest absorbances located at $1614 \mathrm{~cm}^{-1}$ and $3026 \mathrm{~cm}^{-1}$ were selected as representatives of $\mathrm{C}=\mathrm{C}$ and $\mathrm{Ar}-\mathrm{CH}$, respectively. The changes of $\mathrm{C}=\mathrm{C}$ and $\mathrm{Ar}-\mathrm{CH}$ versus temperatures were illustrated in Figs. 12-13.

As can be seen in Fig. 12, C = C in C1 and C2 changed little before the temperatures reached to thresholds which were 371 and $407^{\circ} \mathrm{C}$, respectively. Exceeding these thresholds, rapid decreases of $\mathrm{C}=\mathrm{C}$ were observed. Different from C1 and C2, C = C in C3 kept unchanged during the entire experiment. The changes of $\mathrm{C}=\mathrm{C}$ with temperatures demonstrated that the benzene rings of coal molecules were stable and only participated in reactions at the Combustion Stage.

Curves in Fig. 13 showed that contents of $\mathrm{Ar}-\mathrm{CH}$ in $\mathrm{C} 1$ and $\mathrm{C} 2$ decreased as the temperature rose. However, the decreasing rate of $\mathrm{Ar}-\mathrm{CH}$ in $\mathrm{C} 2$ was lower than that in $\mathrm{C} 1$. Instead of decreasing, $\mathrm{Ar}-\mathrm{CH}$ in $\mathrm{C} 3$ increased when the temperature increased from 25 to $106^{\circ} \mathrm{C}$. Then, the content of $\mathrm{Ar}-\mathrm{CH}$ in $\mathrm{C} 3$ remained constant until the temperature increased to $220^{\circ} \mathrm{C}$. After $220^{\circ} \mathrm{C}, \mathrm{Ar}-\mathrm{CH}$ in $\mathrm{C} 3$ decreased as the increase of the temperature. The behavior of $\mathrm{Ar}-\mathrm{CH}$ in $\mathrm{C} 1$ responded to the temperature indicated that the aromatic nucleus in coal molecules passed high reactivity and would be involved into reactions at the beginning of coal oxidation. Besides, the increase of the $\mathrm{Ar}-\mathrm{CH}$ in $\mathrm{C} 3$ as the increase of the temperature suggested that there was generation of aromatic nucleus during the process of coal oxidation.

\subsection{Characteristics of Free Radicals in Tested Coal Samples}

Fig.14illustrated the EPR spectrograms of tested coal samples. Based on curves in Fig.14 $\mathrm{g}$ factor, line width $(\Delta \mathrm{H})$, and concentrations of free radical $\left(\mathrm{N}_{\mathrm{g}}\right)$ were obtained and listed in Table 4.

It is noticeable in Table 4 that $\mathrm{g}$ factors of tested coal samples ranged from 2.00344 to 2.00264. This notice indicate that free radicals in tested coal samples were organic free radicals regardless of coal properties. Connected with this notice is the observation that a larger $\mathrm{g}$ factor was obtained for a coal sample with lower degree of coalification. Since unpaired electrons of coal were moved along the highly non-localized molecular orbital, orbital magnetic moment of coal was negligible. Consequently, the degree of $\mathrm{g}$ factor deviating from free electron $\left(\mathrm{g}_{\mathrm{e}}\right)$ was determined by the quenching degree of the angular momentum. Generally, a greater quenching degree of the angular momentum resulted in a larger deviation of $\mathrm{g}$ factor from $\mathrm{g}_{\mathrm{e}}$. Combining the interpretation of $\mathrm{g}$ factor with its responses to the coalification leads to the statement: the lower the degree of coalification is, the more unstable of the free 
radicals and the shorter of their survival time are. This was speculated to be the main reason why the coal with lower coalification exhibited higher tendency of spontaneous combustion.

Table 4 Parameters of EPR spectra for tested coal samples.

\begin{tabular}{cccc}
\hline Samples & g Factor & Beam line width $(\Delta \mathrm{H} / \mathrm{mT})$ & Concentration of free radicals $\left(\mathrm{Ng} / 1017 \mathrm{~g}^{-1}\right)$ \\
\hline C1 & 2.00344 & 633.86 & 2.864 \\
C2 & 2.00267 & 619.77 & 19.01 \\
C3 & 2.00264 & 578.25 & 20.16 \\
\hline
\end{tabular}

By comparing data listed in Table 4, it was found that the beam line width $(\Delta \mathrm{H})$ of tested coal samples from high to low was in the order of $\mathrm{C} 1, \mathrm{C} 2$ and $\mathrm{C} 3$. It has been known that beam line width strongly depends on spin - lattice relaxation and spin-spin relaxation. Narrower beam line width indicates longer time of spin-spin relaxation. Longer time of spin-spin relaxation is a reflection of more violent electron exchange among free radicals. Combing this explanation with the analysis of beam line width $(\Delta \mathrm{H})$ listed in Table 4, it can be stated that the intensity of electron exchange among free radicals increased with the increase of the coalification. Further, it can said that chemical reactions in the coal sample with higher degree of coalification was more violent.

As seen in Table 4, the larger concentration of free radicals was observed for the coal sample with higher degree of coalification under the same conditions. This was mainly because the coal sample with higher degree of coalification contained larger amount of fused ring. Generally, benzene rings which were adhered by a variety of branched aliphatic hydrocarbons and oxygen-bearing groups were the backbone of coal molecules. As the development of coalification, those adhered side chains and functional groups separated from benzene rings due to thermolysis and polycondensation. Accordingly, amount of fused ring increased, and free radicals tended to be in stable states. This strongly supported the finding of the $g$ factor that free radicals in lower metamorphic coal were unstable and had shorter survival time. This stable states of free radicals benefited polycondensation of aromatic nucleus. Consequently, even larger and more stable of macromolecular free radical were generated. Simultaneously, the conductivity of electrons was enhanced. Consequently, a higher concentration of free radicals was observed in the coal sample with higher degree of coalification. This finding was in agreement with the analysis of the evolution of aliphatic hydrocarbons as the function of the temperature.

Additionally, it was noticeable in Table 4 that concentrations of free radicals in $\mathrm{C} 1$ were much lower than those in $\mathrm{C} 2$ and $\mathrm{C} 3$. This notice suggested that branched aliphatic hydrocarbons and oxygen-bearing groups of $\mathrm{C} 1$ adhered to aromatic rings by hydrogen bond and /or Van der Waals forces. This suggestion further confirmed previous finding that the contribution of hydrogen bond to the reactivity of coal reduced with the increase of the coalification.

\subsection{Macroscopic Characteristics of Coal Spontaneous Combustion in Relation to Functional Groups}


TG/DSC-FTIR experiments were conducted to investigate macroscopic characteristic parameters of coal spontaneous combustion in relation to functional groups. Figure 15displayed the TG curves of different coal samples during the process of coal spontaneous combustion. As can be seen, an obvious reduction of coal mass could be observed for $\mathrm{C} 1$ at the Dehydration and Desorption Stage ( 25 to $120^{\circ} \mathrm{C}$ ). However, $\mathrm{C} 2$ and $\mathrm{C} 3$ exhibited inconspicuous changes in coal mass at is stage. As explained in the section regarding the evolution of $-\mathrm{OH}$ as the temperature, $-\mathrm{OH}$ could react with oxygen molecules spontaneously. According to principle of chemical reactions, the main oxidation product of $-\mathrm{OH}$ in coal was water. Therefore, it was expected to obtain corresponding water vapor generation for $\mathrm{C} 1$ at this stage. Figure 16 illustrated the profiles of water vapor productions during the process of coal spontaneous combustion. As can be seen, a high generation of water vapor was observed for $\mathrm{C} 1$, agreeing well with the expectation. Consequently, it can be said that the mass loss of coal samples at the Dehydration and Desorption Stage mainly attributed to the oxidation of $-\mathrm{OH}$.

Additionally, the absorbed oxygen molecules would react with coals following the procedures in Eqs. 13 at the Oxidation Stage and thus increase the coal mass. This interpretation conformed well to the observations illustrated in Fig. 16. Consequently, it sufficed to say that the generation of intermolecularassociated $-\mathrm{OH}$ was the main cause leading to the mass increase during the coal spontaneous combustion. Further analysis of TG curves in Fig. 16found that the increment of mass for C3 was higher than that of $\mathrm{C} 2$ at the oxidation stage. This finding was the evidence of the statement drawn from the analysis of the beam line width $(\Delta \mathrm{H})$ that chemical reactions in the coal sample with higher degree of coalification was more violent.

\section{Conclusions}

To investigate the mechanism of coal spontaneous combustion, three coals with different properties were subjected to in-situ FTIR experiments and EPR experiments. Besides, the macroscopic characteristic parameters of coal spontaneous combustion in relation to functional groups were correlated via TG/DSCFTIR experiments.

Analysis of FTIR spectra found that that the contents of functional groups in coals from low to high was in an order of aliphatic hydrocarbons, aromatic hydrocarbons, and oxygen-bearing groups regardless of coal properties. With the increase of the coalification, both aliphatic hydrocarbons and aromatic hydrocarbons increased gradually while the content of oxygen-bearing groups decreased. Along the same line, the contribution of the hydrogen bond for the reactivity of coal was diminished. $-\mathrm{OH}$ was validated to be the most active group during the spontaneous combustion. It could not only react with oxygen spontaneously, but also be generated by the chemisorption of oxygen. Besides, $-\mathrm{OH}$ was validated to contribute most to the mass decrease as well as the increase during the process of coal spontaneous combustion by TG/DSC-FTIR experiments. Different from -OH, energy was indispensable in inducing the reactions between aliphatic hydrocarbons and oxygen. As the oxidation product of aliphatic hydrocarbons, $\mathrm{C}=\mathrm{O}$ was an important transition groups of coal spontaneous combustion. Responses of $\mathrm{C}=\mathrm{C}$ and $\mathrm{Ar}-\mathrm{CH}$ to the temperature indicated that benzene rings of coal sample were quite stable and 
could only involve into reactions after ignition. Nevertheless, aromatic rings exhibited relative high reactivity and would participate into reactions at the beginning of coal oxidation. Also, it was found that aromatic rings were generated during the process of coal spontaneous combustion.

Analysis of EPR spectra found that free radicals in coal were limited into organic elements. With the increase of the coalification, the content of macromolecular free radical increased. Simultaneously, both the stability and survive time of free radicals enhanced. In addition to this, a higher concentration of free radicals was obtained to be in the coal sample with higher degree of coalification due to increased fused rings. Accordingly, more violent chemical reactions were observed in the coal sample of higher coalification.

\section{Declarations}

\section{Acknowledgements}

This research was finically supported by National Key R\&D Program of China (2018YFC0807900), National Natural Science Foundation of China (Grant Nos. 51774233, 51604218, 51974235) and Natural Science Foundation of Shaanxi Province (Grant Nos. 2018JZ5007, 2018JM512).

\section{References}

Cerny J, Pavlikova H (1994) Structural analysis of low rank coal extract and their relation to parent coal. Energy Fuel 8(2):375-379.

Classification of coals, ISO 11760-2005, ISO/TC27.

Dack SW, Hobday MD, Smith TD, Pilbrow JR (1983) Free radical involvement in the oxidation of Victorian brown coal. Fuel 62: 1510-1512.

Dai GL (2011) Comprehensive Experimental study on low temperature oxidation and spontaneous combustion of coal. Xuzhou: China University of Mining and Technology press. pp: 45-53.

Deng J, Yang Y, Zhang YN, Liu B, Shi CM (2018) Inhibition effect of three commercial inhibitors for spontaneous coal combustion. Energy 160: 1174-1185.

Dyrkacz GR, Bloomquist CA (2015) Binary solvent extractions of upper freeport coal. Energy Fuel 15(6): 1409-1413.

Fei J, Li WY, Xie KC (2002) Research on coal structure using FTIR. Journal of China University of Mining \& Technology 5: 362-366.

Ibarra J, Munoz E, Moliner R (1996) FTIR study of the evolution of coal structure during the coalification process. Organic Geochemistry 24(6/7): 725-735. 
Kudynska J, Buckmaster HA (1996) Low-temperature oxidation kinetics of high-volatile bituminous coal studied by dynamic in situ $9 \mathrm{GHz}$ c. w. e. p. r. spectroscopy. Fuel 75: 872-878.

Li CQ, Takanohash IT, Saito I (2002) The behavior of free radicals in coal at temperatures up to $300{ }^{\circ} \mathrm{C}$ in various organic solvents, using in situ EPR spectroscopy. Energy Fuel 16(5): 1116-1120.

Li ZH (1996) Mechanism of free radical reaction in spontaneous combustion of coal. Journal of China University of Mining \& Technology 25(3): 111-114.

Liotta R, Brons G, Isaacs J (1983) Oxidative weathering of Illinois No. 6 Coal. Fuel 63: 781-791.

Liu JX, Jiang XM, Han XX, Shen J, Zhang H (2014) Chemical properties of superfine pulverized coals. Part 2. Demineralization effects on free radical characteristics. Fuel 115(12): 685-696.

Liu JX, Jiang XM, Shen J, Zhang H (2015) Influences of particle size, ultraviolet irradiation and pyrolysis temperature on stable free radicals in coal. Powder Technol 272, 64-74.

Mathews JP, Chaffee AL (2012) The molecular representations of coal: A review. Fuel 96: 1-14.

Petersen $\mathrm{HI}$ (2006a) The petroleum generation potential and effective oil window of humic coals related to coal composition and age. International Journal of Coal Geology 67(4): 221-248.

Petersen HI, Nytoft HP (2006b) Oil generation capacity of coals as a function of coal age and aliphatic structure. Organic Geochemistry 37(5): 558-583.

Pilar G, Peter J, Fanor M (1999) The use of differential scanning calorimetry to identify coals susceptible to spontaneous combustion. Thermochimica Acta 336 (1-2): 41-46.

Pilawa B, Więckowski AB, Pietrzak R, Wachowska H (2002) Oxidation of demineralized coal and coal free of pyrite examined by EPR spectroscopy. Fuel 81(15): 1925-1931.

Pis JJ, Puente G, Fuentea E, Moránb A, Rubiera F (1996) A study of the self- heating of fresh and oxidized coals by differential thermal analysis. Thermochim Acta 279(6): 93-101.

Retcofsky HL, Stark JM, Friedel RA (1968) Electron spin resonance in American coals. Analytical Chemistry 40(11): 1699-1704.

Shi T, Deng J, Wang XF, Wang ZY (2004) Mechanism of spontaneous combustion of coal at initial stage. Journal of Fuel Chemistry and Technology 6: 652-657.

Shi T, Wang XF, Deng J, Wang ZY (2005) The mechanism at the initial stage of the room-temperature oxidation of coal. Combust Flame 140:332-345.

Wang DM (2008) Science of Mine fire. Xuzhou: China University of Mining and Technology press pp: 4753. 
Wang DM, Xin HH, Qi XY, Dou GL, Zhong XX (2014) Mechanism and relationships of elementary reactions in spontaneous combustions of coal: The coal oxidation kinetics theory and application. Journal of China Coal Society 39(08): 1667-1674.

Wang DM, Xin HH, Qi XY, Dou GL, Zhong XX (2014) Mechanism and relationships of elementary reactions in spontaneous combustion of coal: The coal oxidation kinetics theory and application. Journal of china coal society 39(9): 1667-1674.

Wang JR, Jin ZX, Deng CB (2014) Quantum Chemical Theory of Coal Spontaneous Combustion. Beijing: Science Press. pp: 189-202.

Wang K (2013) Study on the oxidation and spontaneous combustion characteristics of Jurassic coal in Northern Shaanxi. Master Thesis in the Xi'an University of Science and Technology.

Wood SU, Harris IJ (1992) Effects of drying methods on the low temperature reactivity of Victorian brown coal to oxygen. Fuel 71(2): 183-192.

Xiao Y, Ma L, Wang ZP, Deng J, Wang W, Xiang X (2007) Research on characteristic temperature in coal spontaneous combustion with thermal gravity analysis method. Coal Science and Technology 05: 73-76.

Xu T, Wang DM, Xin HH, Qi XY (2019) Experimental study on the temperature rising characteristic of spontaneous combustion of coal. Journal of Mining \& Safety Engineering 29(04): 575-580.

Xu YL, Wang LY, Tian N, Zhang JP, Yu MG (2017) Spontaneous combustion coal parameters for the Crossing-Point Temperature(CPT) method in a Temperature-Programmed System(TPS).Fire Safety Journal 91: 147-154.

Yang S (2005) Study on the active groups' reaction activeness on self-ignition coal. Coal Mine Modernization 65: 59-60.

YU MG, Jia HL, Yu SJ, Pan RK (2006) Calculation of micro-structure parameter of Wuda bituminous coal and relationship-analysis between coal structure and coal spontaneous combustion. Journal of China Coal Society 31(5): 610-614.

Yu MG, Zheng YM, Lu C, Jia HL (2009) Thermal analysis experiment on low-temperature oxidation and pyrolysis of coal. China Safety Science Journal 09: 83-86.

Zhang YN (2013) Study on the microcosmic characteristics and macro parameters in the process of coal oxidation and spontaneous combustion. PhD Thesis in the Xi'an University of Science and Technology.

Zhang YT, Shi XQ, Li YQ, Wen H, Huang Y, Li SS, Liu YR (2017) Inhibiting effects of Zn/Mg/Al layer double hydroxide on coal spontaneous combustion. Journal of China Coal Society 42(11): 2892-2899. 
Zhang YT, Li YQ, Huang Y, LI SS, Wang WF (2018a) Characteristics of mass, heat and gaseous products during coal spontaneous combustion using TG/DSC-FTIR technol. Journal of Thermal and Analysis Calorimetry 131(3): 2963-2974.

Zhang YT, Shi XQ, Li YQ, Liu YR (2018b) Characteristics of carbon monoxide production and oxidation kinetics during the decaying process of coal spontaneous combustion. Canadian Journal of Chemical Engineering 96:1752-1761.

Zhang YT, Liu YR, Shi XQ , Yang CP, Wang WF, Li YQ (2018c) Risk evaluation of coal spontaneous combustion on the basis of auto-ignition temperature. Fuel 233: 68-76.

Zhang YT, Yang CP, Li YQ, Huang Y, Zhang J, Zhang YB, Li QP (2019) Ultrasonic extraction and oxidation characteristics of functional groups during coal spontaneous combustion .Fuel 242:287-294.

Cerny J, Pavlikova H (1994) Structural analysis of low rank coal extract and their relation to parent coal. Energy Fuel 8(2):375-379.

Classification of coals, ISO 11760-2005, ISO/TC27.

Dack SW, Hobday MD, Smith TD, Pilbrow JR (1983) Free radical involvement in the oxidation of Victorian brown coal. Fuel 62: 1510-1512.

Dai GL (2011) Comprehensive Experimental study on low temperature oxidation and spontaneous combustion of coal. Xuzhou: China University of Mining and Technology press. pp: 45-53.

Deng J, Yang Y, Zhang YN, Liu B, Shi CM (2018) Inhibition effect of three commercial inhibitors for spontaneous coal combustion. Energy 160: 1174-1185.

Dyrkacz GR, Bloomquist CA (2015) Binary solvent extractions of upper freeport coal. Energy Fuel 15(6): 1409-1413.

Fei J, Li WY, Xie KC (2002) Research on coal structure using FTIR. Journal of China University of Mining \& Technology 5: 362-366.

Ibarra J, Munoz E, Moliner R (1996) FTIR study of the evolution of coal structure during the coalification process. Organic Geochemistry 24(6/7): 725-735.

Kudynska J, Buckmaster HA (1996) Low-temperature oxidation kinetics of high-volatile bituminous coal studied by dynamic in situ $9 \mathrm{GHz}$ c. w. e. p. r. spectroscopy. Fuel 75: 872-878.

Li CQ, Takanohash IT, Saito I (2002) The behavior of free radicals in coal at temperatures up to $300{ }^{\circ} \mathrm{C}$ in various organic solvents, using in situ EPR spectroscopy. Energy Fuel 16(5): 1116-1120.

Li ZH (1996) Mechanism of free radical reaction in spontaneous combustion of coal. Journal of China University of Mining \& Technology 25(3): 111-114. 
Liotta R, Brons G, Isaacs J (1983) Oxidative weathering of Illinois No. 6 Coal. Fuel 63: 781-791.

Liu JX, Jiang XM, Han XX, Shen J, Zhang H (2014) Chemical properties of superfine pulverized coals. Part 2. Demineralization effects on free radical characteristics. Fuel 115(12): 685-696.

Liu JX, Jiang XM, Shen J, Zhang H (2015) Influences of particle size, ultraviolet irradiation and pyrolysis temperature on stable free radicals in coal. Powder Technol 272, 64-74.

Mathews JP, Chaffee AL (2012) The molecular representations of coal: A review. Fuel 96: 1-14.

Petersen $\mathrm{HI}$ (2006a) The petroleum generation potential and effective oil window of humic coals related to coal composition and age. International Journal of Coal Geology 67(4): 221-248.

Petersen HI, Nytoft HP (2006b) Oil generation capacity of coals as a function of coal age and aliphatic structure. Organic Geochemistry 37(5): 558-583.

Pilar G, Peter J, Fanor M (1999) The use of differential scanning calorimetry to identify coals susceptible to spontaneous combustion. Thermochimica Acta 336 (1-2): 41-46.

Pilawa B, Więckowski AB, Pietrzak R, Wachowska H (2002) Oxidation of demineralized coal and coal free of pyrite examined by EPR spectroscopy. Fuel 81(15): 1925-1931.

Pis JJ, Puente G, Fuentea E, Moránb A, Rubiera F (1996) A study of the self- heating of fresh and oxidized coals by differential thermal analysis. Thermochim Acta 279(6): 93-101.

Retcofsky HL, Stark JM, Friedel RA (1968) Electron spin resonance in American coals. Analytical Chemistry 40(11): 1699-1704.

Shi T, Deng J, Wang XF, Wang ZY (2004) Mechanism of spontaneous combustion of coal at initial stage. Journal of Fuel Chemistry and Technology 6: 652-657.

Shi T, Wang XF, Deng J, Wang ZY (2005) The mechanism at the initial stage of the room-temperature oxidation of coal. Combust Flame 140:332-345.

Wang DM (2008) Science of Mine fire. Xuzhou: China University of Mining and Technology press pp: 4753.

Wang DM, Xin HH, Qi XY, Dou GL, Zhong XX (2014) Mechanism and relationships of elementary reactions in spontaneous combustions of coal: The coal oxidation kinetics theory and application. Journal of China Coal Society 39(08): 1667-1674.

Wang DM, Xin HH, Qi XY, Dou GL, Zhong XX (2014) Mechanism and relationships of elementary reactions in spontaneous combustion of coal: The coal oxidation kinetics theory and application. Journal of china coal society 39(9): 1667-1674. 
Wang JR, Jin ZX, Deng CB (2014) Quantum Chemical Theory of Coal Spontaneous Combustion. Beijing: Science Press. pp: 189-202.

Wang K (2013) Study on the oxidation and spontaneous combustion characteristics of Jurassic coal in Northern Shaanxi. Master Thesis in the Xi'an University of Science and Technology.

Wood SU, Harris IJ (1992) Effects of drying methods on the low temperature reactivity of Victorian brown coal to oxygen. Fuel 71(2): 183-192.

Xiao Y, Ma L, Wang ZP, Deng J, Wang W, Xiang X (2007) Research on characteristic temperature in coal spontaneous combustion with thermal gravity analysis method. Coal Science and Technology 05: 73-76.

Xu T, Wang DM, Xin HH, Qi XY (2019) Experimental study on the temperature rising characteristic of spontaneous combustion of coal. Journal of Mining \& Safety Engineering 29(04): 575-580.

Xu YL, Wang LY, Tian N, Zhang JP, Yu MG (2017) Spontaneous combustion coal parameters for the Crossing-Point Temperature(CPT) method in a Temperature-Programmed System(TPS).Fire Safety Journal 91: 147-154.

Yang S (2005) Study on the active groups' reaction activeness on self-ignition coal. Coal Mine Modernization 65: 59-60.

YU MG, Jia HL, Yu SJ, Pan RK (2006) Calculation of micro-structure parameter of Wuda bituminous coal and relationship-analysis between coal structure and coal spontaneous combustion. Journal of China Coal Society 31(5): 610-614.

Yu MG, Zheng YM, Lu C, Jia HL (2009) Thermal analysis experiment on low-temperature oxidation and pyrolysis of coal. China Safety Science Journal 09: 83-86.

Zhang YN (2013) Study on the microcosmic characteristics and macro parameters in the process of coal oxidation and spontaneous combustion. PhD Thesis in the Xi'an University of Science and Technology.

Zhang YT, Shi XQ, Li YQ, Wen H, Huang Y, Li SS, Liu YR (2017) Inhibiting effects of Zn/Mg/Al layer double hydroxide on coal spontaneous combustion. Journal of China Coal Society 42(11): 2892-2899.

Zhang YT, Li YQ, Huang Y, LI SS, Wang WF (2018a) Characteristics of mass, heat and gaseous products during coal spontaneous combustion using TG/DSC-FTIR technol. Journal of Thermal and Analysis Calorimetry 131(3): 2963-2974.

Zhang YT, Shi XQ, Li YQ, Liu YR (2018b) Characteristics of carbon monoxide production and oxidation kinetics during the decaying process of coal spontaneous combustion. Canadian Journal of Chemical Engineering 96:1752-1761. 
Zhang YT, Liu YR, Shi XQ , Yang CP, Wang WF, Li YQ (2018c) Risk evaluation of coal spontaneous combustion on the basis of auto-ignition temperature. Fuel 233: 68-76.

Zhang YT, Yang CP, Li YQ, Huang Y, Zhang J, Zhang YB, Li QP (2019) Ultrasonic extraction and oxidation characteristics of functional groups during coal spontaneous combustion .Fuel 242:287-294.

\section{Figures}

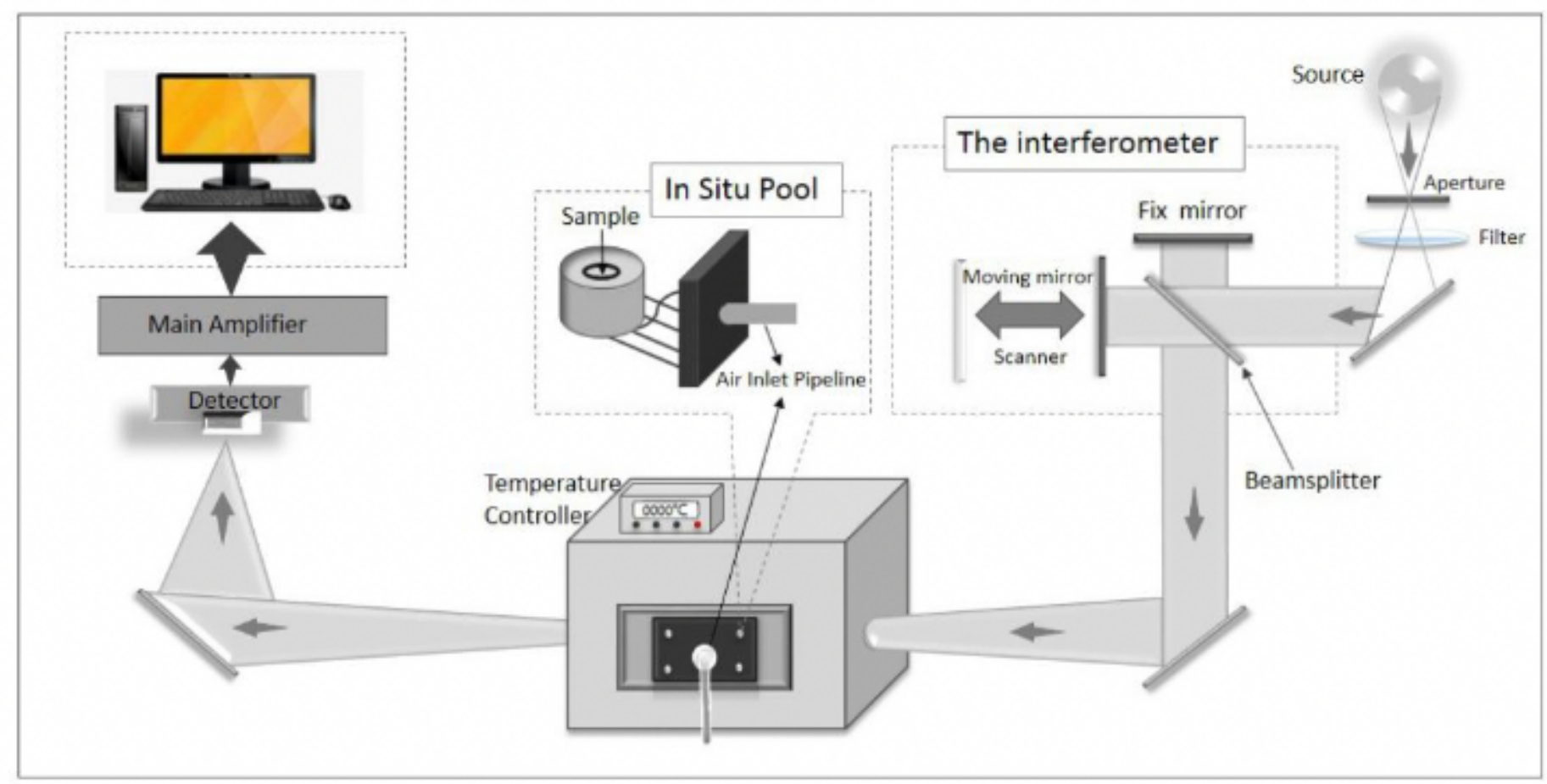

Figure 1

Schematic of the in-situ FTIR system 


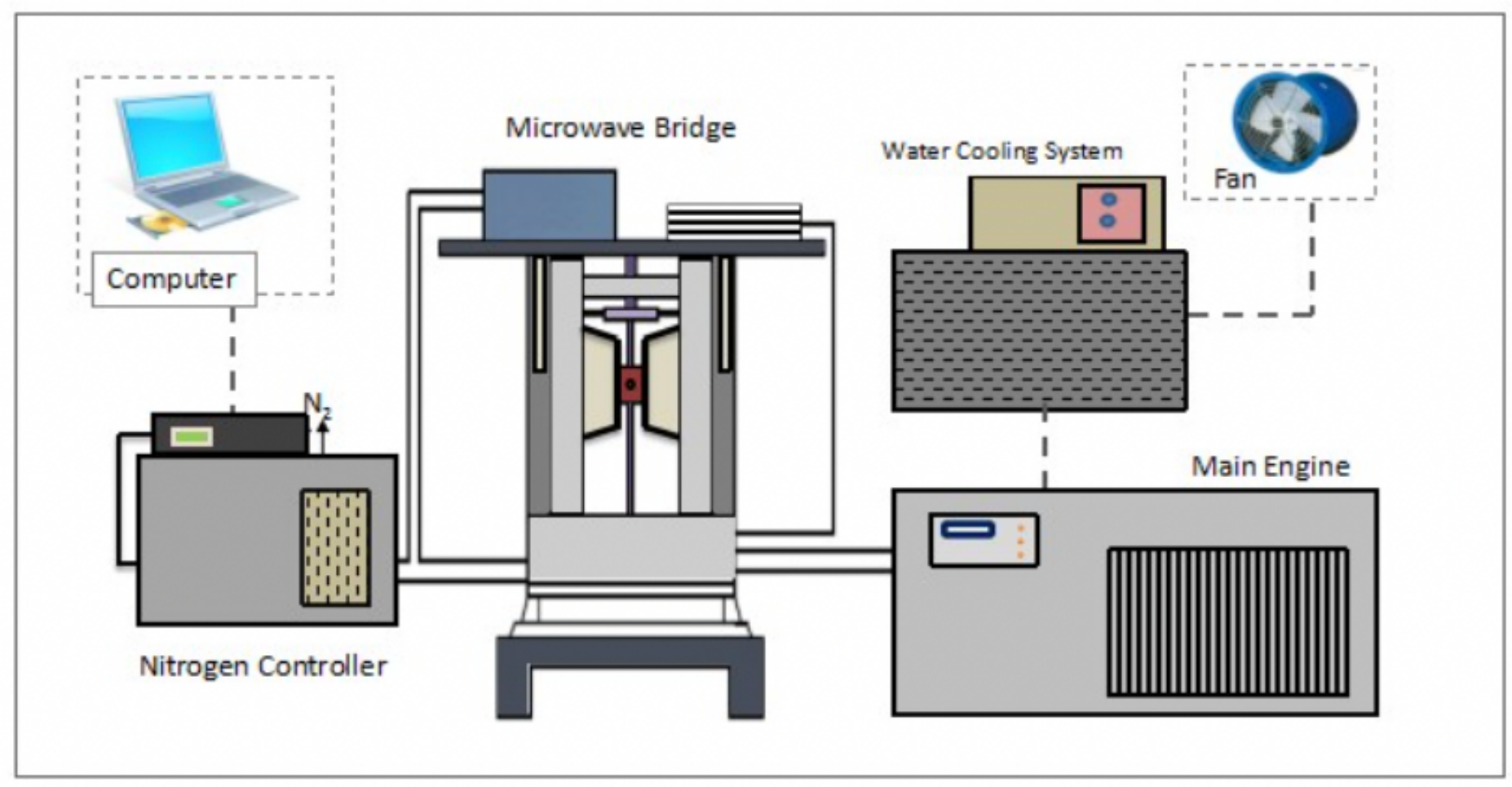

Figure 2

Schematic of the EPR system

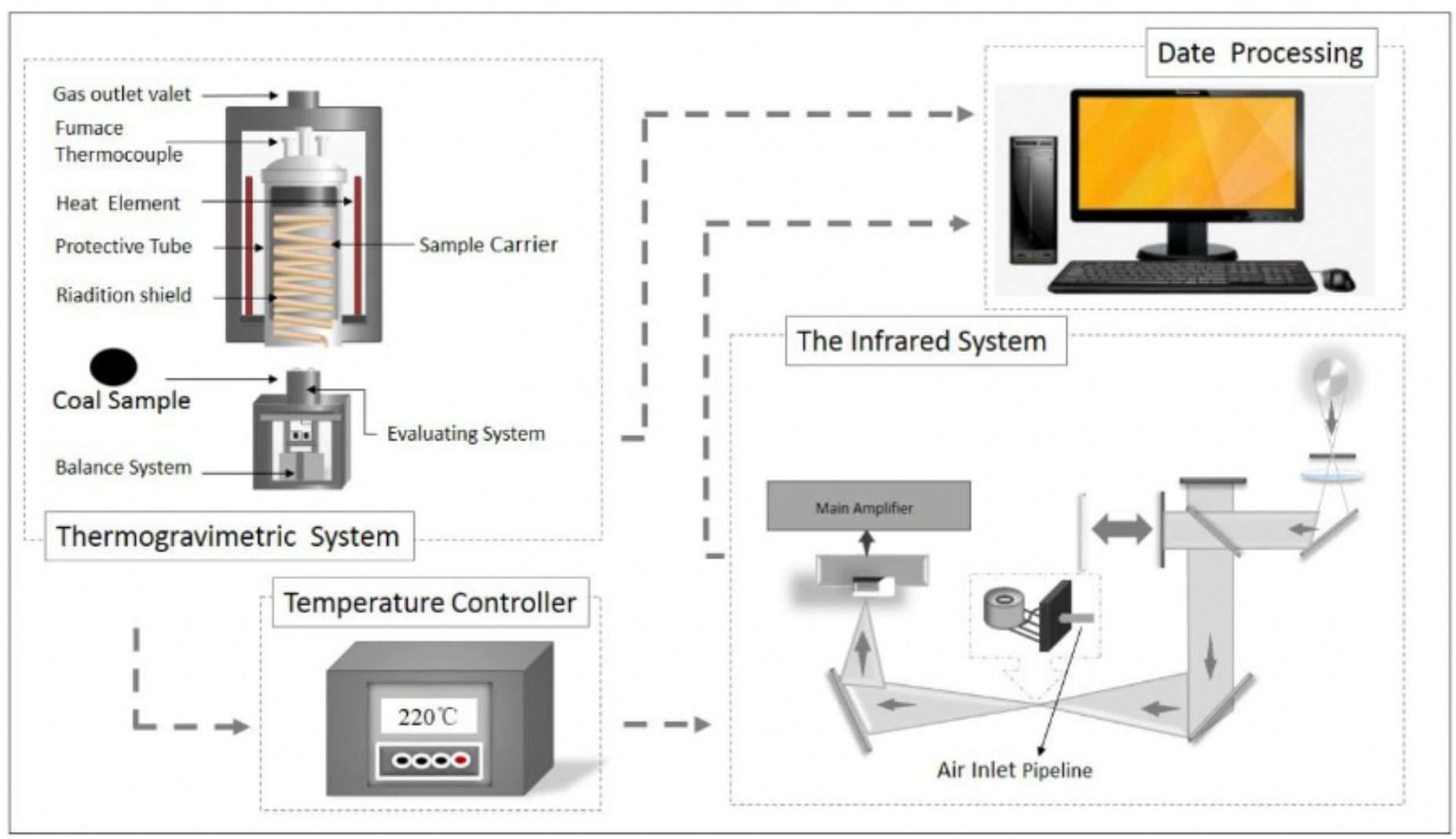

Figure 3 

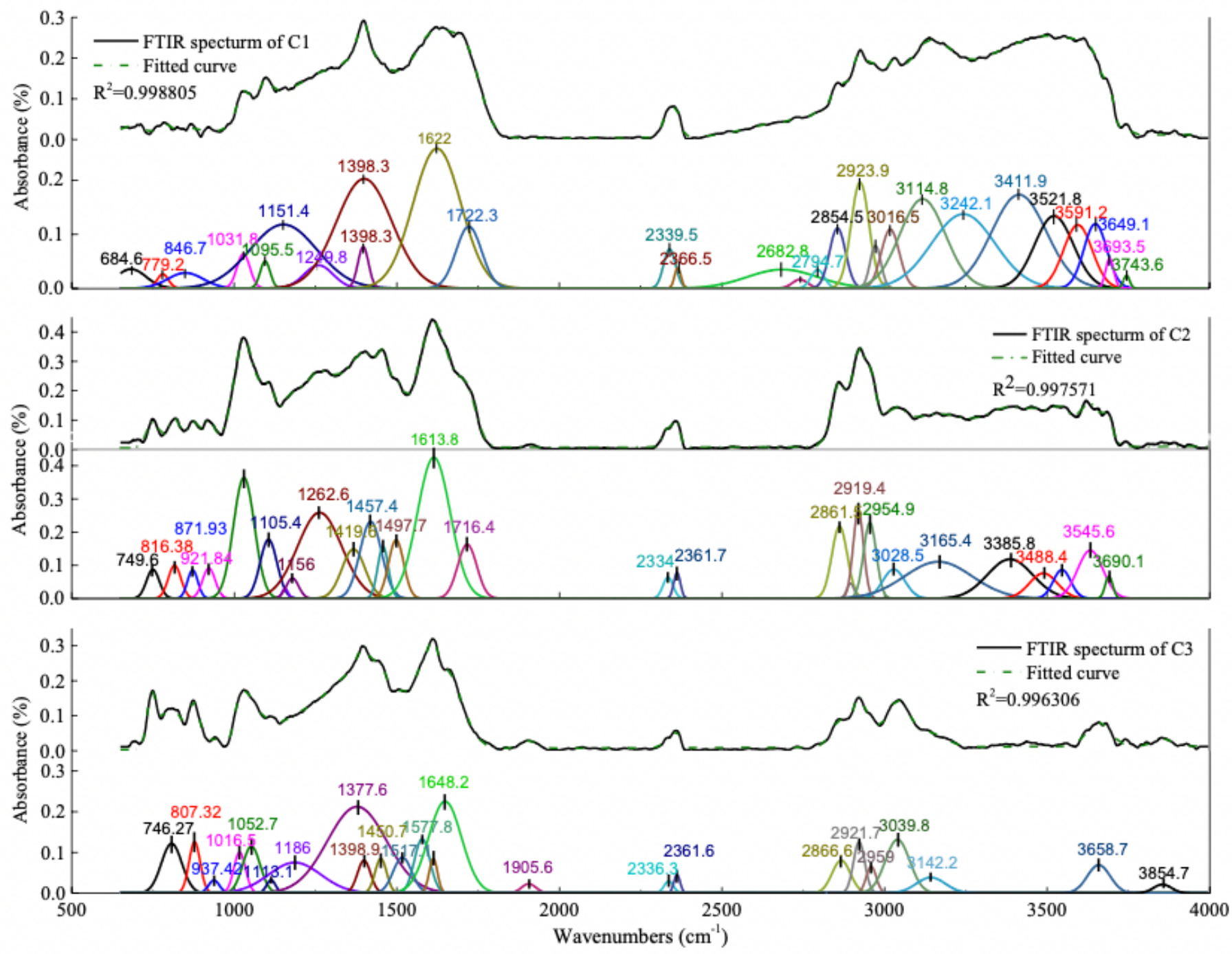

\section{Figure 4}

FTIR spectra of different samples 


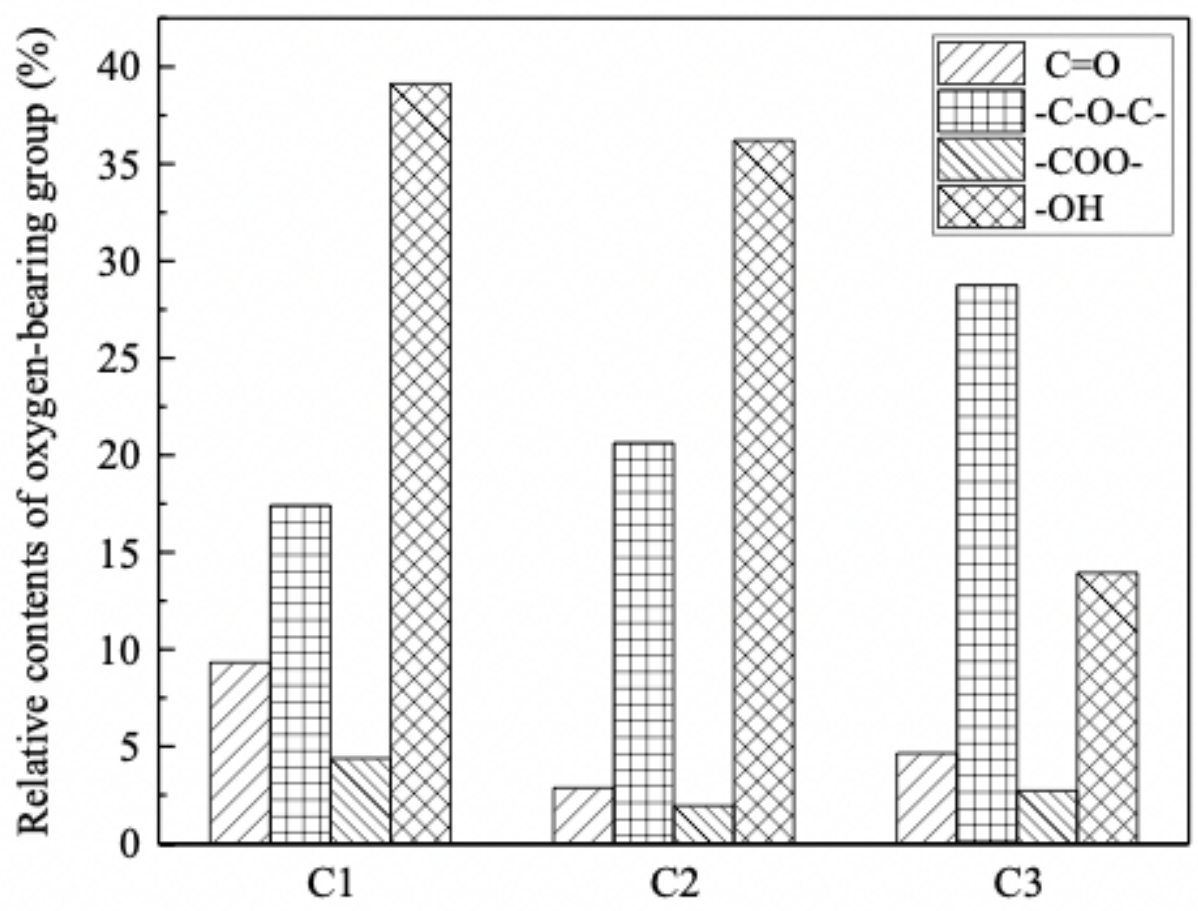

Figure 5

Relative contents of the oxygen-bearing groups in different coal samples

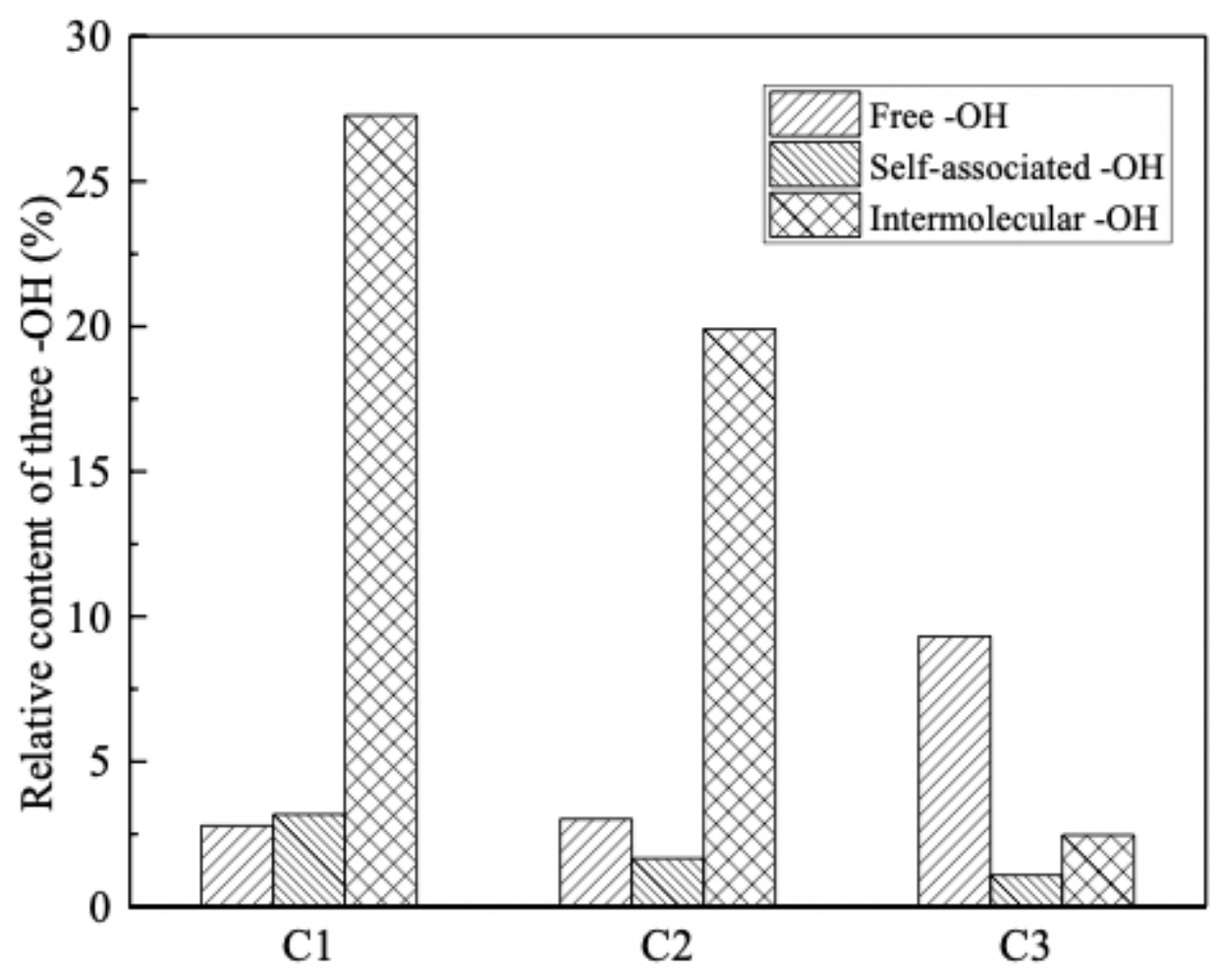

Figure 6 
Different forms of $-\mathrm{OH}$ distributed in coal samples

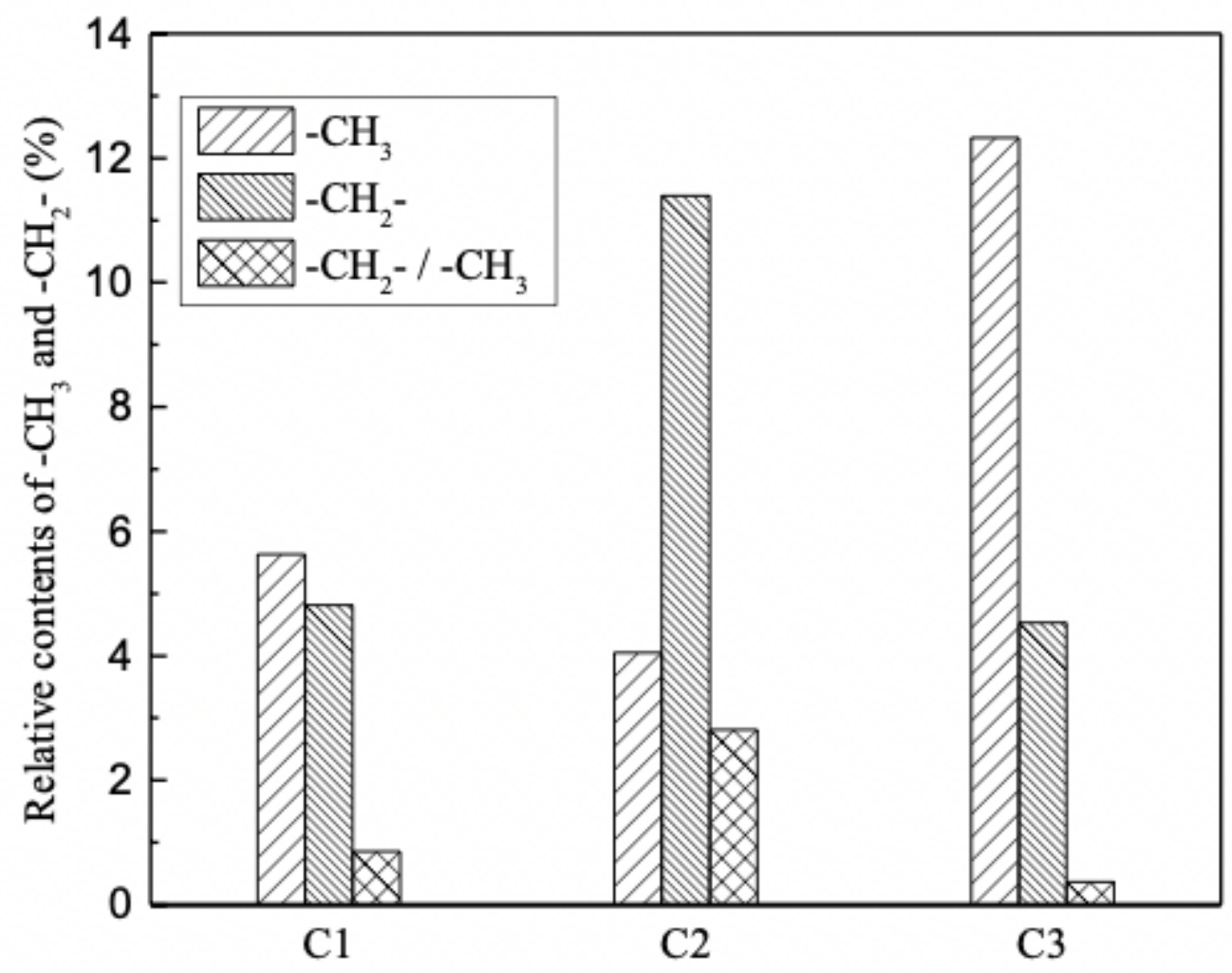

Figure 7

Distributions of - $\mathrm{CH} 2$ - and - $\mathrm{CH} 3$ in different coal samples

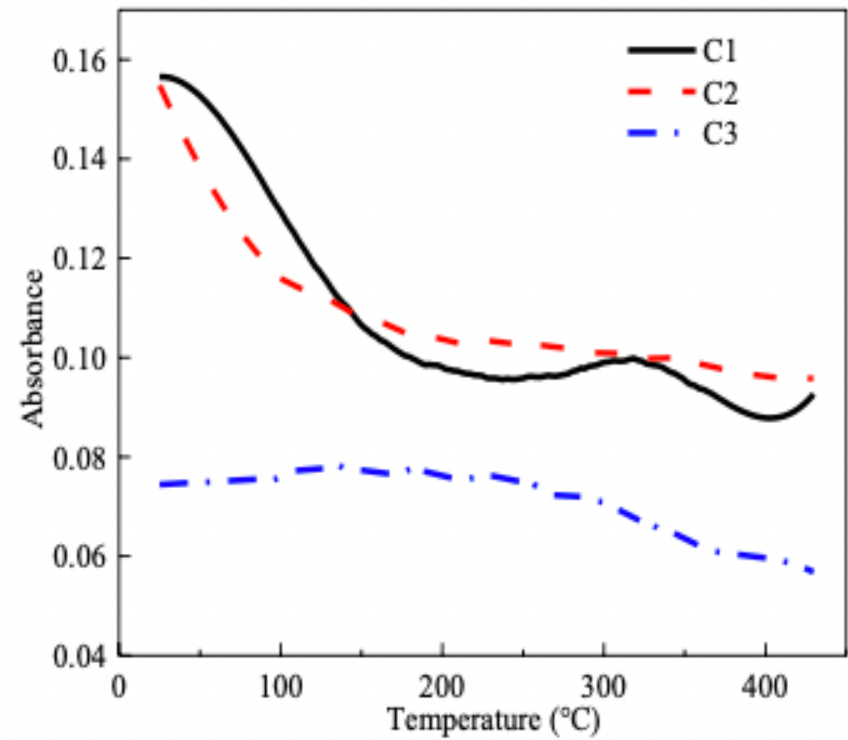

(a) Free $-\mathrm{OH}\left(3674 \mathrm{~cm}^{-1}\right)$

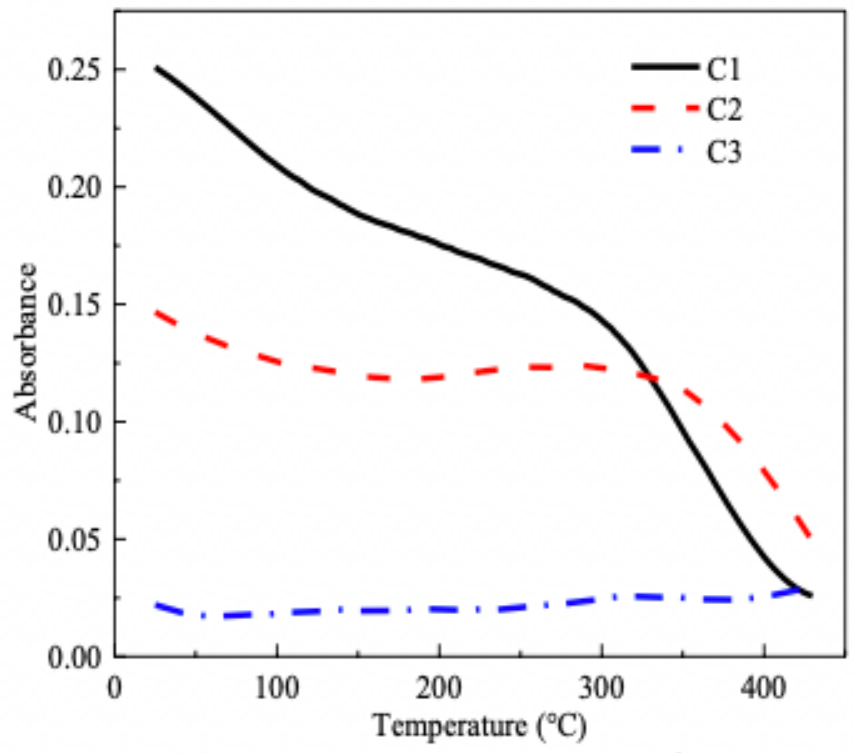

(b) Intermolecular-associated-OH $\left(3535 \mathrm{~cm}^{-1}\right)$

Figure 8 
Evolution of $-\mathrm{OH}$ with the increase of the temperature

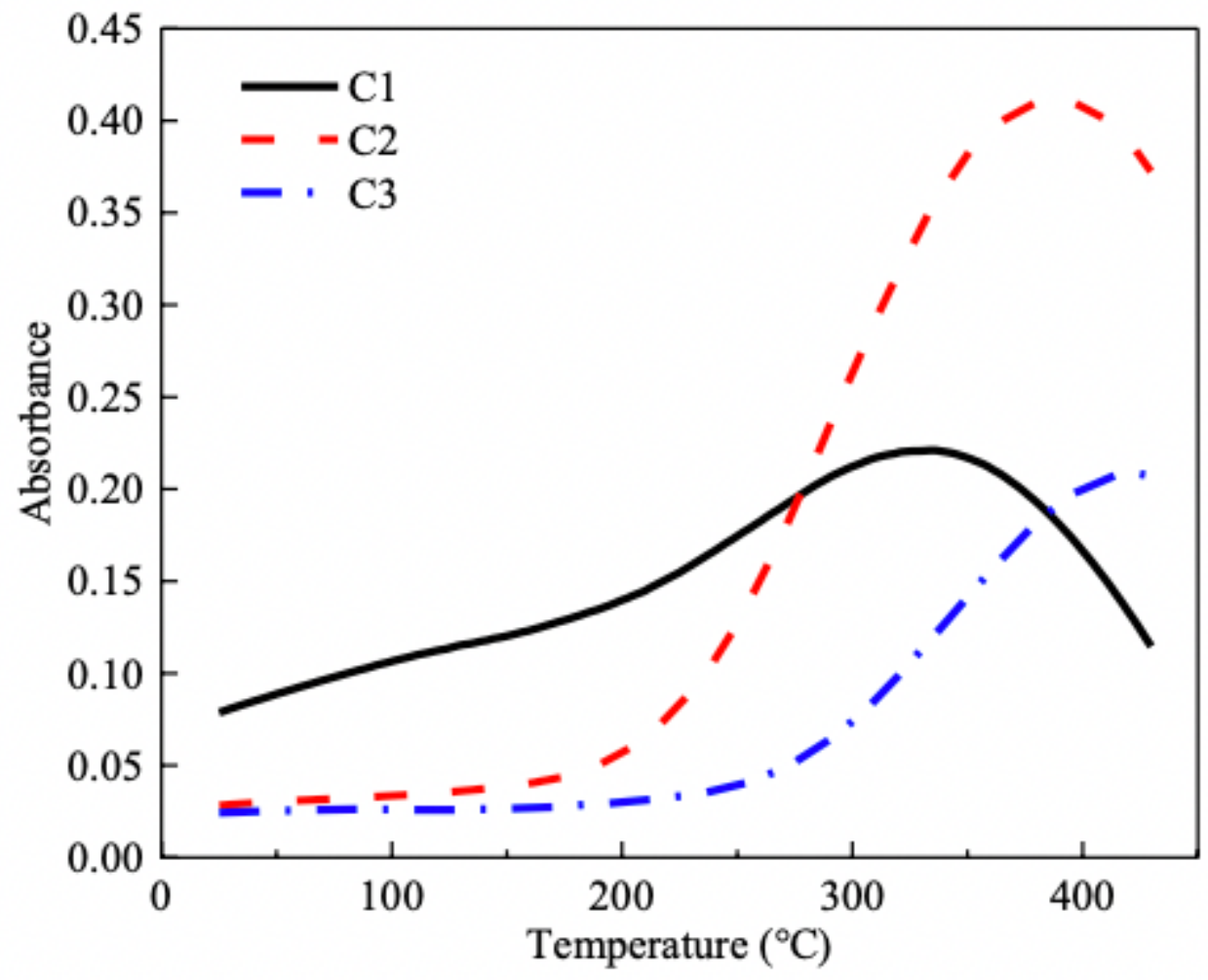

Figure 9

Evolution of $\mathrm{C}=0$ with the increase of the temperature $(1776 \mathrm{~cm}-1)$

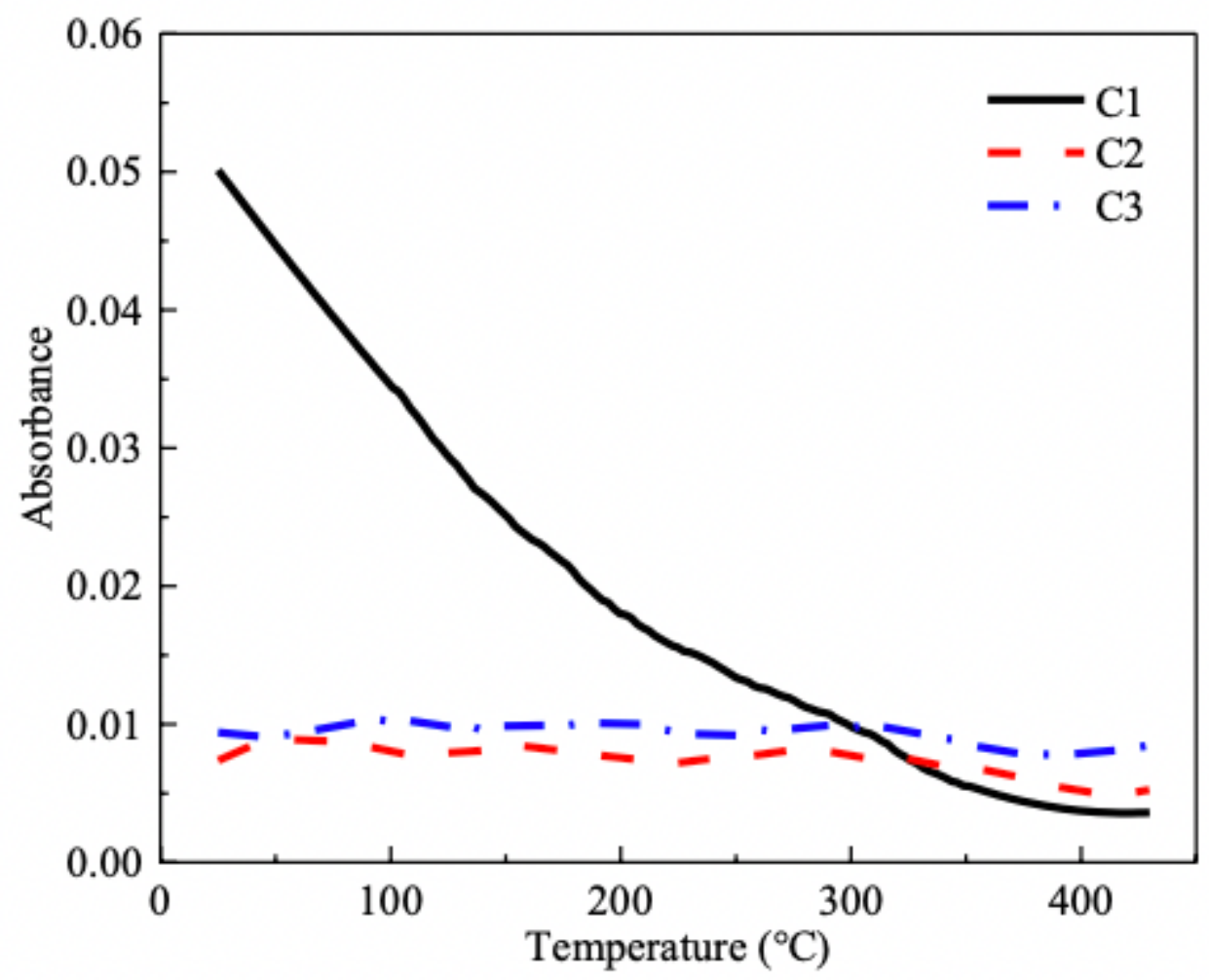


Figure 10

Evolution of -COO- as the functional of the temperature $(2733 \mathrm{~cm}-1)$

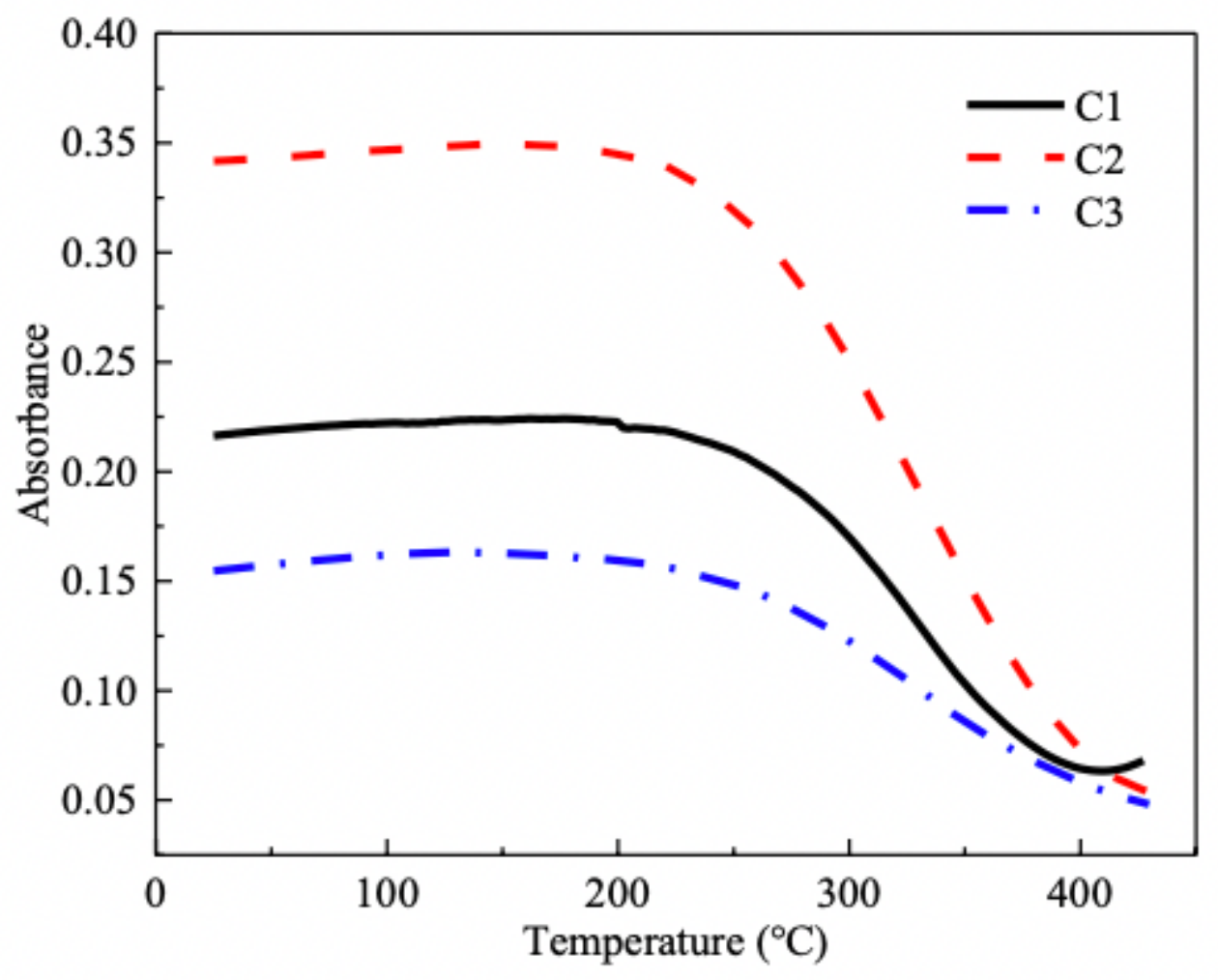

Figure 11

Evolution of $\mathrm{C}-\mathrm{H}$ bond in $-\mathrm{CH} 2-$ and $-\mathrm{CH} 3$ as the functional of the temperature for various coals $(2918 \mathrm{~cm}-$ 1) 


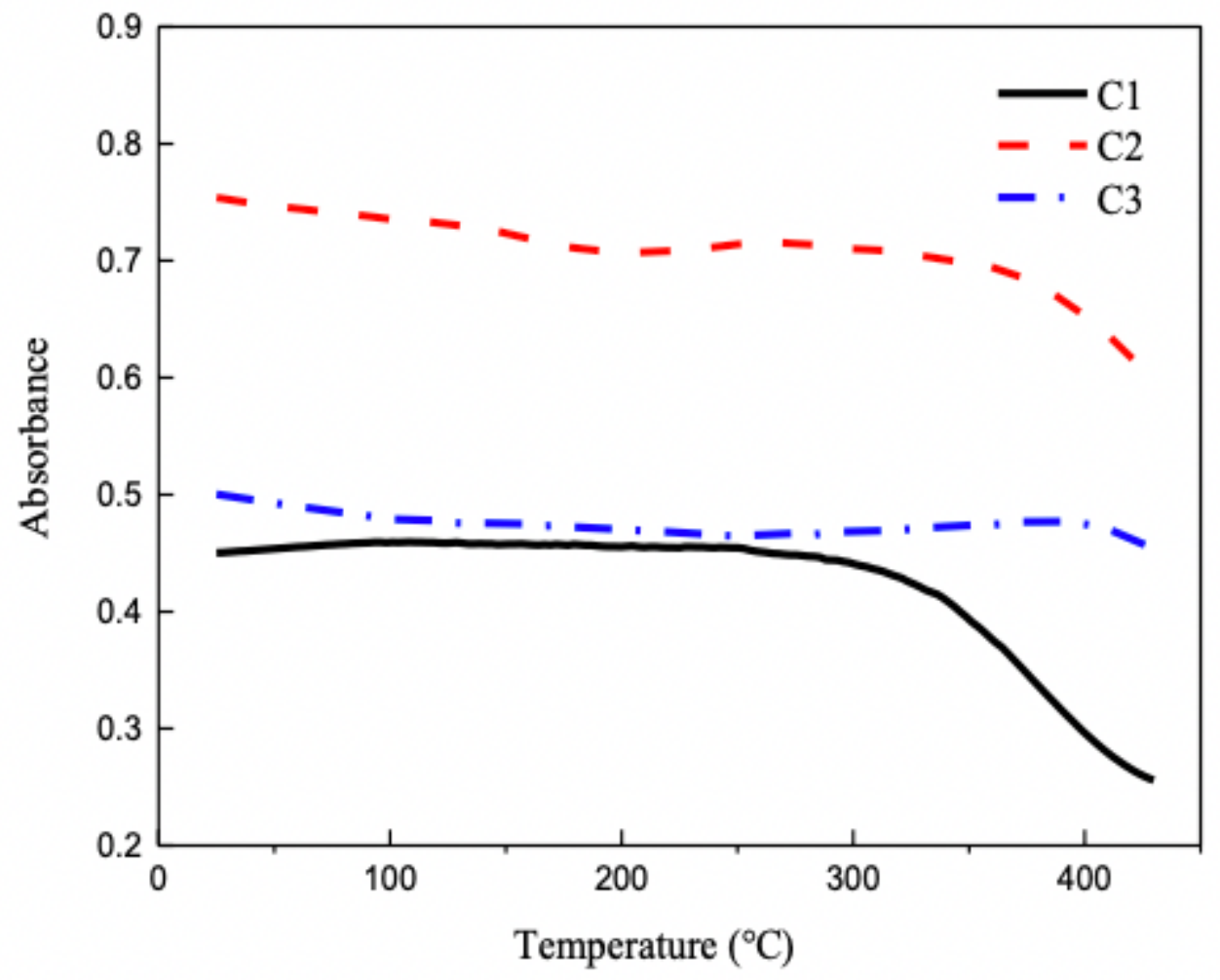

Figure 12

Evolution of aromatic nucleus $(\mathrm{C}=\mathrm{C})$ in different coal samples as the functional of the temperature (1614 $\mathrm{cm}-1$ ) 


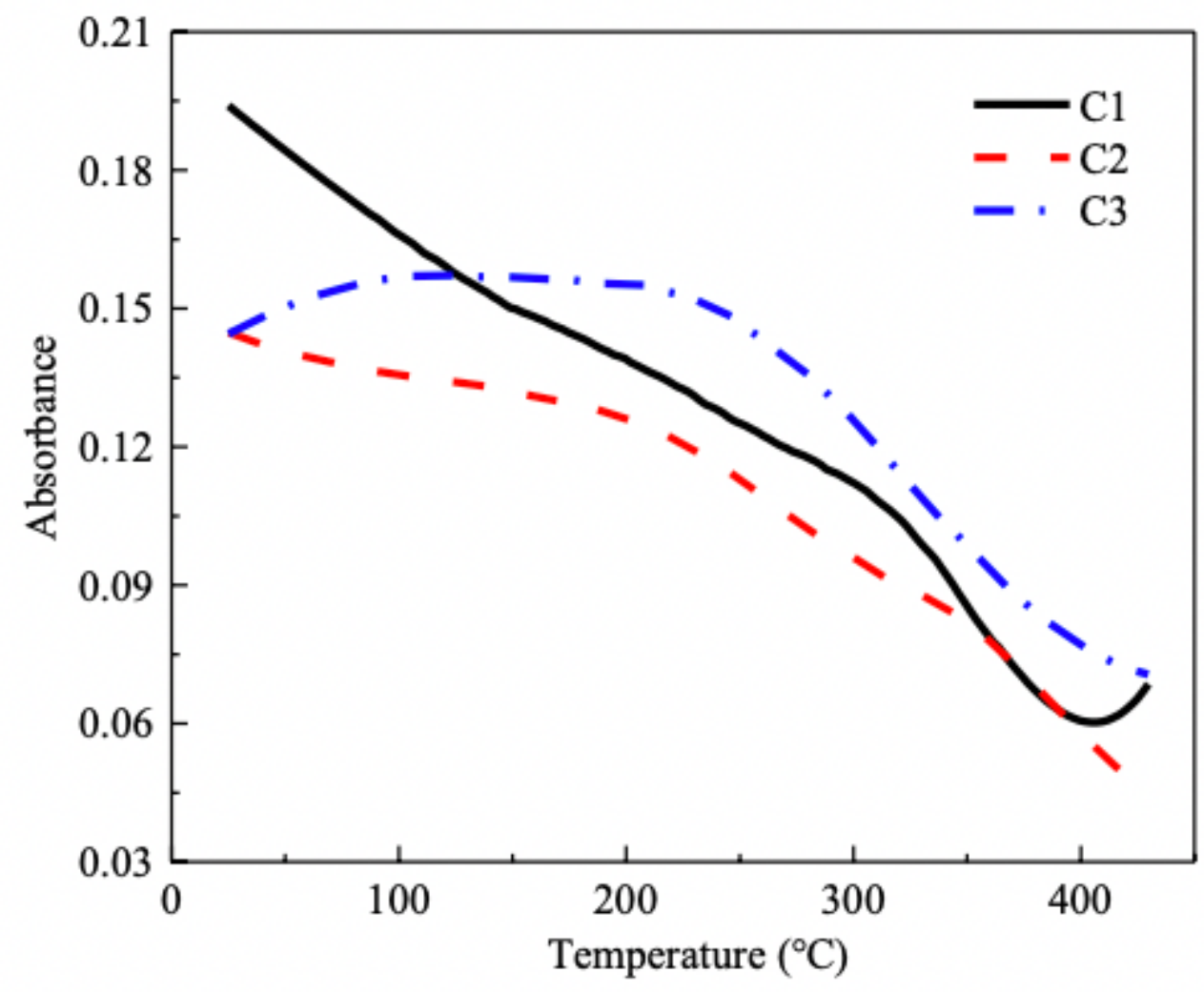

Figure 13

Evolution of aromatic hydrogen $(\mathrm{Ar}-\mathrm{CH})$ in different coal samples as the functional of the temperature $(3026 \mathrm{~cm}-1)$ 


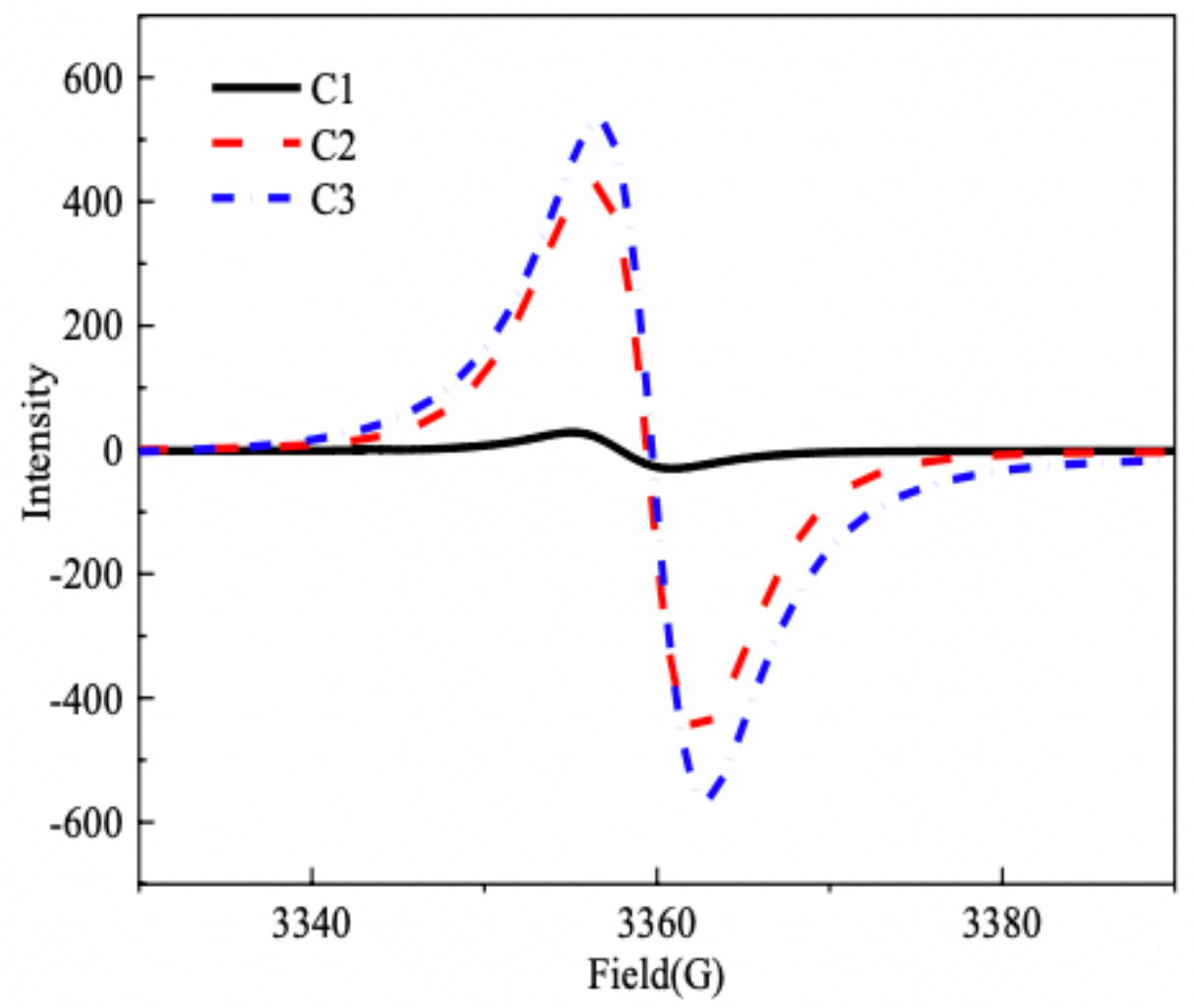

Figure 14

EPR spectra of tested coal samples

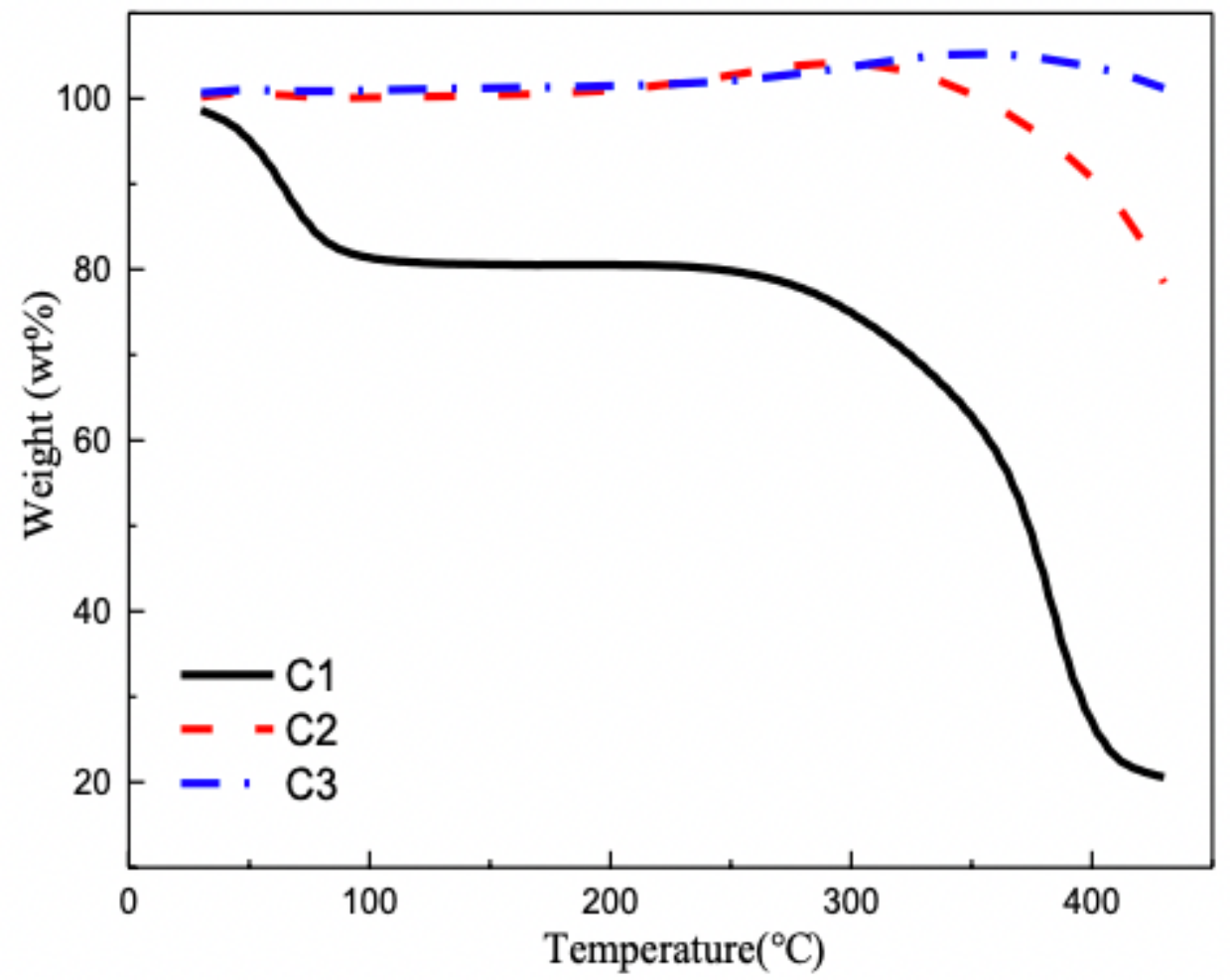


Figure 15

TG/DTG curves of different coal samples

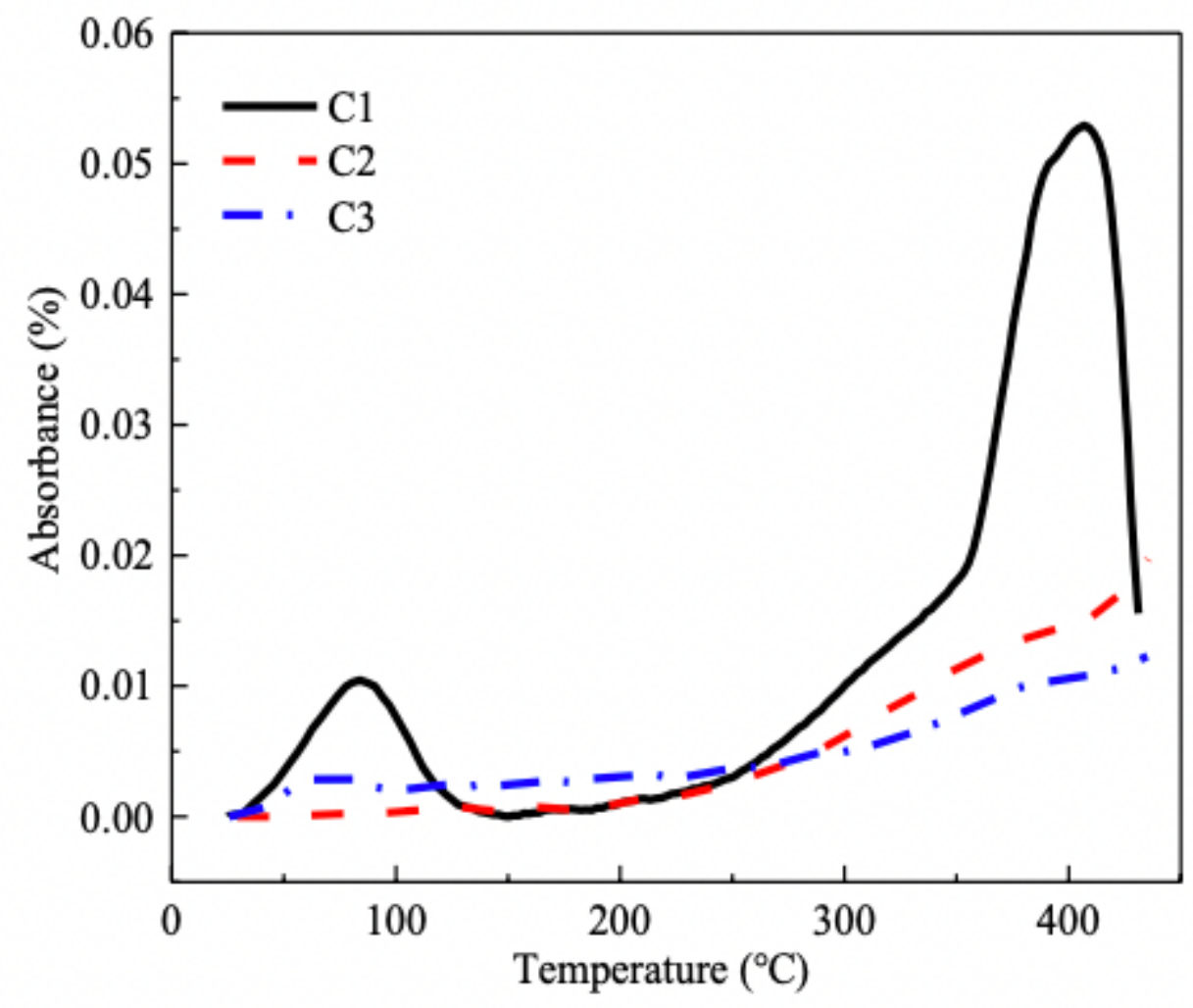

Figure 16

Profile of water vapor released during the spontaneous combustion of coal $(3735 \mathrm{~cm}-1)$ 